WORKING PAPERS No. 54

\title{
THE COMING TRANSFORMATION OF CONTINENTAL EUROPEAN BANKING?
}

by

William R. White

June 1998

BANK FOR INTERNATIONAL SETTLEMENTS

Monetary and Economic Department

BASLE 
BIS Working Papers are written by members of the Monetary and Economic Department of the Bank for International Settlements, and from time to time by outside economists, and are published by the Bank. The papers are on subjects of topical interest and are technical in character. The views expressed in them are those of their authors and not necessarily the views of the BIS.

(C) Bank for International Settlements 1998

CH-4002 Basle, Switzerland

Also available on the BIS World Wide Web site (http://www.bis.org).

All rights reserved. Brief excerpts may be reproduced or translated provided the source is stated.

ISSN 1020-0959 


\title{
THE COMING TRANSFORMATION OF CONTINENTAL EUROPEAN BANKING?*
}

by

William R. White

June 1998

\begin{abstract}
This paper first provides a broad overview of current conditions in the banking industry in some of the countries that will participate in European economic and monetary union. It then goes on to identify a number of important forces for change. Some of these are global in nature, but likely to have a particularly strong impact in continental Europe, while others (such as the introduction of the euro) are distinctively European. The paper then notes just how little restructuring has actually taken place in continental European banking in the last decade and offers some explanations. The conclusion reached is that the banking sector in continental Europe may now be about to enter a period of sharply increased competition. This will pose challenges for national regulators and other policy-makers concerned with the maintenance of financial stability.
\end{abstract}

* I would like to thank Angelika Donaubauer, Jens Ulrich and Monica Horgan for their help in assembling the background material (especially the tables) for this paper. Useful comments were also received from Claudio Borio, Gabriele Galati, Pablo Graf, Costas Tsatsaronis and Philip Turner. None of the above bear any responsibility for the final product. 



\section{Contents}

Introduction

1. Continental European banking: the starting-point

2. Forces for change in continental European banking $\quad$.................................................... 3

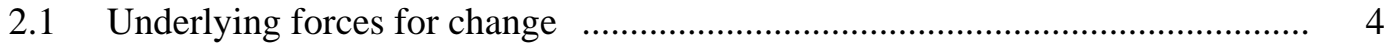

2.2 Manifestations of underlying forces …………........................................... $\quad 9$

2.3 Multiplicative effects and the bottom line ................................................... 12

3. Broad forces impeding change in continental European banking $\ldots \ldots \ldots \ldots \ldots \ldots \ldots \ldots \ldots \ldots \ldots . . . . . . . . . . . . . . .13$

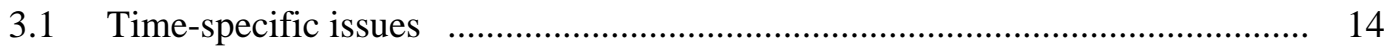

3.2 Institutional and cultural impediments to change …..................................... 14

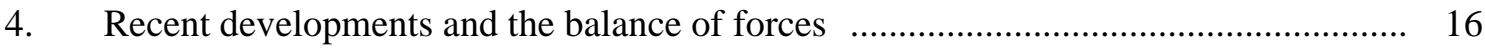

5. Conclusions and some implications for public policy …......................................... 23

Tables

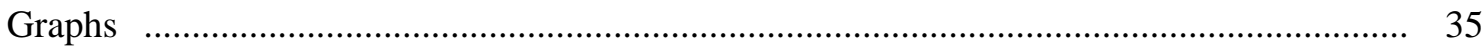

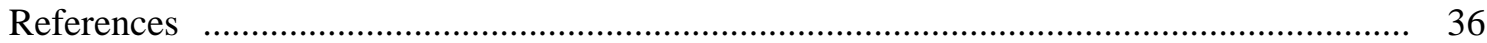





\section{Introduction}

This paper first provides a broad overview of the current state of the banking industry in the major countries that will enter the European economic and monetary union. It then goes on to identify some important forces for change and some important forces resisting change in European banking. Among the former are included changes in technology, the evolving role of the state, demographic pressures, a growing concern for shareholder value and (of course) the introduction of the euro. Globalisation, securitisation and growing competition from both non-bank financial intermediaries and unregulated non-banks are treated as manifestations of underlying and more fundamental forces for change. Among the forces resisting change are some which seem likely to disappear with time. However, other such forces supporting the status quo arise from long-standing institutional and cultural patterns which are not likely to be altered quickly. Attention is paid finally to some recent developments at both the intra-firm and inter-firm level and what they indicate about how the balance of forces is playing out.

The broad conclusion of the paper is that the banking sector in continental Europe seems poised for a period of sharply increased competition. This will create opportunities for many, but also challenges for the private sector and the public sector alike. Important policy issues include establishing the degree of national consolidation likely to enhance efficiency whilst maintaining competition. Closely related are prudential issues having to do with ensuring financial stability during a period of heightened competition. Finally, unlikely as this outcome may be, there is the issue of effective crisis management under EMU, given that supervisory responsibilities remain at the national level while the European Central Bank has a supranational character.

\section{Continental European banking: the starting-point ${ }^{1}$}

In both continental Europe and the English-speaking countries ${ }^{2}$ financial claims have for many years grown faster than the overall size of the economy. Nevertheless, banks in these two groups of countries have not benefited to the same degree from this longer-term trend. In continental Europe, traditional bank lending is of significantly greater importance than in the English-speaking

1 It is appropriate to begin this paper, as I did an earlier one, with a health warning. The intention is to try to provide a brief summary of some very broad trends in the European financial community. In this process, assertions will be made that do not apply at all (or only in part) to banks from particular national jurisdictions. For individual banks, broad statements may be even less applicable.

2 In this paper, unless otherwise stated, the continental European countries should be taken to refer to Austria, Belgium, France, Germany, Italy, the Netherlands and Spain. All of these countries will be members of EMU and subject in consequence to enhanced competitive pressures. Unfortunately, resource constraints did not allow consideration of the banking sectors in all prospective EMU countries. References to English-speaking countries typically imply the United Kingdom and the United States. 
(Anglo) countries where the direct sale of securities to ultimate lenders is much more widespread. Moreover, this divergence has tended to be more noticeable as the quality of the credit diminishes; junk bonds and equity issues by small and medium-sized enterprises are almost unknown in Europe and the securitisation of credit is also relatively undeveloped. ${ }^{3}$

Within the realm of financial intermediation, banks in continental Europe have a much larger share of total intermediated claims than do banks in the other group of countries. These differences are well documented in Davis (1996) and Dermine (1997) and imply a greater reliance on impersonal markets in English-speaking countries and a greater reliance on relationship banking in continental Europe. Should European financial structures come increasingly to resemble the Anglo model, the degree of adjustment required from European banks would certainly be large. As is discussed below, there are many forces leading in this direction, although there are also many forces supporting the status quo.

In the continential European banking system, corporate and retail banking services continue to be overwhelmingly provided by "national" corporate entities. Wholesale banking, in contrast, is intensely competitive and highly international, due in large part to the existence of offshore and "euro" markets which have supported such trends. Table 1 shows the limited share of bank assets (credit) and liabilities (deposits) that is accounted for by cross-border business within Europe. A recent study on behalf of the Banking Advisory Committee of the European Union ${ }^{4}$ also notes that there were only 486 cross-border branches in the whole European Union in December 1995, which represents about one-third of $1 \%$ of all bank branches (including head offices) 5

The principal thesis of this paper is that continental European banks may be about to enter a period of enhanced competition. If this is so, the starting position for many banks is not particularly strong. As indicated by a comparison of Tables 2 and 3, the rate of return on the assets of banks in some continental countries rebounded in 1995 and in many cases rose further in 1996. However, this should not overshadow a number of underlying trends. The rate of return on both assets and equity continues to be relatively low in some countries (compared with US, UK and restructured Nordic banks) and profits seem to have been trending down since the mid-1980s (see Table 3). Net interest margins, which have traditionally been squeezed by the provision of "preferential credits" to long-standing customers, have tended to narrow further. Loan loss provisions have also been high, ${ }^{6}$ a

3 See Jeanneau (1996).

4 See Economic Research Europe Ltd. (1996).

5 The total number of branches was taken from Table 9 below.

6 Much of this can be related to losses on loans collateralised with commercial property. The value of such property fell sharply through the first half of the 1990s in many continental European countries (albeit with wide regional variations), though the implications for the profit and loss account tended to be recognised only with a lag. 
by-product of the earlier period of deregulation. Finally, employment costs as a proportion of gross income are also high by international standards (see Moody's (1998)).

Reflecting these realities, the ratio of bank share prices to general stock price indices has been on a declining trend in many European countries (see Table 4). While bank shares have rebounded (relative to the index) in the last year or so, it is interesting that the shares of banks in English-speaking countries have generally performed even better. ${ }^{7}$ It is also a fact that downgradings of continental banks by rating agencies have become more common (see Graph 1), even if credit ratings remain relatively high. In sum, there is at least a prima facie case that a significant degree of restructuring is required.

Some other simple comparisons also give the impression that continental European banks tend to be too small and have too many branches. On the one hand, the degree to which total bank assets are concentrated in the top five to ten banks in each individual European country (see Table 5) is not obviously different from most non-European countries; indeed, in this respect the United States and Germany are clear outliers. On the other hand, the much more pertinent question is the extent to which market forces might lead to increased concentration within a single European market. Measured against aggregate numbers for Europe as a whole, all European banks still look individually very small. The number of bank branches per person in some continental European countries also seems to exceed norms in the English-speaking countries even though the Europeans generally have smaller geographical catchment areas. ${ }^{8}$ Of course, comparisons of this sort clearly suffer from the need to determine which group of countries is "normal".

\section{Forces for change in continental European banking}

In recent months, the possible implications of the introduction of the euro for the European banking industry have received increasing attention. ${ }^{9}$ Yet there is danger in such a focus in that many other powerful forces encouraging change within European banking may be ignored. While the euro may act as a catalyst for change, it is the underlying forces that will play a more important role in shaping the direction of that change. Some of these forces are very deep (e.g. technological change and demographic trends) and are affecting banking developments worldwide, while some other commonly identified forces (e.g. globalisation and securitisation) are better thought of as manifestations of deeper forces. Finally, it bears mentioning that dynamic interactions between forces for change can, in some circumstances, lead to a sudden acceleration of change more akin to a regime

\footnotetext{
7 Whether any of these gains will be sustained should there be a general market correction is of course an open question.

8 See Barth et al. (1996), Table 3.

9 See McCauley and White (1997) and the references therein.
} 
shift. The sudden collapse of the socialist regimes in Eastern Europe and the profound recent change in the fortunes of a number of economies in East Asia illustrate that change is not always linear. The marked transformation of the British financial industry since the "Big Bang" in 1986 indicates that similar changes may be possible in banking as well.

\subsection{Underlying forces for change}

Changes in technology, deregulation, attitudes to shareholder value and demographic trends in the industrial countries are affecting the financial business everywhere. Yet there are grounds for arguing, of which the lack of adaptation to date is only one, that the prospective influence of these factors may be greater in continental Europe than in the English-speaking countries. The introduction of the euro is also a distinctively European event, even if the implications of this event do extend well beyond continental Europe itself.

Perhaps the most fundamental force for change in the financial sector has been developments in technology, in particular computing and telecommunications, the fruits of which are available to non-banks as well as banks. These influences have led to a whole host of new financial products and a great expansion in the means to deliver them. Sharp reductions in computer costs and the application of financial engineering now allow the various risks implicit in any single financial instrument (market risk, credit risk and liquidity risk) to be unbundled and sold or purchased separately. Moreover, the same technology now allows these risks to be rebundled (pooled) in such a way that modern portfolio theory can be applied to the management of both the risks and the returns. Such developments underlie recent trends to securitisation, the development of various derivative products (including credit derivatives) ${ }^{10}$ and the application of "credit-scoring" techniques to consumer finance, credit cards and mortgages. Most of these procedures are relatively underdeveloped in continental Europe. ${ }^{11}$

Delivery systems for financial products have also become much more sophisticated. Analogous to the unbundling of risks, this implies that the delivery of services can also be unbundled. Telephone banking is now well established in many countries and ATMs are seen virtually everywhere and are increasingly sophisticated. The provision of financial services on the Internet is

10 Reductions in computing costs in the process of conducting "due diligence" also encourage securitisation. A further, more prosaic aspect of technology which encourages securitisation is the use of identical common forms by different financial institutions in granting credits of various sorts. This practice is now almost universal with respect to mortgages in the United States.

11 See Jeanneau (1996). 
also beginning to expand rapidly. While the base is still relatively small, ${ }^{12}$ Internet customers also tend to be "high-end" purchasers of financial services who make a disproportionate contribution to profits. The Internet now provides access to extraordinary amounts of financial information (including competitive prices for deposits and loans) as well as facilities to receive investment advice and carry out transactions. Lower-priced computers, further advances in technology, ${ }^{13}$ greater familiarity and increased confidence in the security of the technology will accelerate these trends.

These technological developments have a number of implications. The first constitutes a direct attack on the "relationship banking" which continues to be at the heart of most European banking systems. ${ }^{14}$ By allowing the unbundling and rebundling of products, and their separable delivery to the customer, technology contributes to a general commoditisation of products. In turn, this encourages competition, product by product, on the basis of price alone rather than historical relationships. The fact that information about these products will be increasingly available and cheap will work in the same direction. Even if countervailing forces ensure that relationship banking in Europe may continue to thrive, ${ }^{15}$ it is likely to become increasingly difficult to continue with current practices of effective cross-subsidisation. Individual customers, aware of alternatives, will increasingly refuse to cross-subsidise other bank customers ${ }^{16}$ who contribute less to the bottom line. Perhaps more important, cross-subsidising individual products will become increasingly expensive as competitors "cherry pick" in areas where they feel they have a competitive advantage. ${ }^{17}$

Finally, the availability of alternative delivery systems for financial products will increasingly call into question the viability of European branch banking systems and the concept of "one-stop shopping". ${ }^{18}$ It is not obvious that customers prefer this form of receiving services; in particular, short opening hours conflict with a growing desire for convenience. Nor indeed is it obvious that all-purpose branches can provide services with the required degree of flexibility and efficiency. If an analogy can be made to the competition between general department stores and

12 The Bank of America estimates that $10 \%$ of its retail customers now bank regularly on-line. In Germany, the German Centre for Information Banking estimates that 31/2 million Germans are now doing at least some part of their banking online. This is a 60\% increase from last year. See Rhoads and Ascarelli (1998).

13 The newest focus of attention in the United States is the market for computers costing less than $\$ 750$. Wider bandwidths to increase access speeds, cheap access to the Web via television sets and interactive TV technology will all work in the direction of increasing access to the Internet. See Stewart (1997).

14 For a fuller analysis of such issues see Chernow (1997).

15 See the discussion of new business orientations below. Perhaps of greatest relevance here, the technology can also be used to tailor packages of products to individual clients.

16 Berlin and Mester (1996) argue that multiperiod lending relationships require the availability of cheap (below market rate) deposits.

17 See Llewellyn (1996), pp. 156-7.

18 See Freedman and Goodlet (1998). 
specialised merchandisers in a number of countries, the latter are increasingly dominating the former. ${ }^{19}$ At the very least, the purpose of branches will have to be reassessed.

A second force for change in European banking is the changing role of the state. Banks which are owned or strongly supported by the state (for example, mutual and cooperative banks, often having a regional nature) have traditionally played a very significant role in France, Italy, Germany and Spain among other countries (see Table 6). Moreover, other indirect means of providing state support for national banking systems (or parts of it) are also common. For example, certain banks in Germany have their credits guaranteed by the Länder with which they are associated. Some rough measure of the importance of such support is provided by comparing the Moody's rating based on inherent financial strength and the rating based on implicit government support (see Table 7). It also remains the case that the banking industry in continental Europe (as elsewhere) is very heavily regulated and that public policy in this area has until recently tended to emphasise considerations relating to "stability" more than those of "efficiency".

The state has also played a role, albeit inadvertent, in discouraging the development of other forms of financial markets. The fact that state-supported social security funds are so welldeveloped in continental Europe, and that they have generally been of the unfunded variety (indeed this is commonly true of pensions provided by large corporates as well), has in large part removed the need for private saving plans and the market infrastructure needed to support them. This approach stands in sharp contrast to the United States, where the largest state interventions in the credit markets have been the guarantee of a large fraction of mortgage credit and the provision of tax breaks for funded stand-alone pensions. Both of these incentives have encouraged the development of the securities markets at the expense of bank assets.

However, the role of the state in European banking is now beginning to change in virtually all the respects described above. In Austria, France and Italy, steps have been taken to reduce direct state ownership of banks. ${ }^{20}$ As for other forms of state support, the problems of Crédit Lyonnais have led the European Commission to focus much more carefully on the proper treatment of ailing banks within the context of the Maastricht Treaty. A similar concern, but about ongoing state support for otherwise competitive banks, was highlighted by the recent visit of the German Banking Association (representing private banks) to the European Commission to complain about the injection of "allegedly" free capital into Westdeutsche Landesbank (Germany's largest public sector bank). The failure of the Amsterdam Summit of June 1997 to ratify a proposed amendment to the Maastricht

19 In Canada and the United States, department stores are increasingly being reinvented as single physical spaces where separate stores (generally associated with brand names) are grouped.

20 Most recently, a French parliamentary commission made a proposal on 8th April 1998 to transform the Caisse d'Épargne from a state-owned institution into a cooperative. 
Treaty, giving the German Sparkassen and Landesbanken special status, was another small step in the direction of a diminishing state role in the financial industry. ${ }^{21}$

Excessive regulation in the financial sector has been recognised as a problem for over 30 years, ${ }^{22}$ but attempts to deal with it have been stepped up sharply this decade. ${ }^{23}$ Against a background of continuing high costs for financial services in individual European countries (discussed below), the Second Banking Coordination Directive was passed by the EC Council of Ministers in December 1990, and came into effect on 1st January 1993. Based on the clear principles of a single "passport" (allowing financial activity anywhere in the Community), mutual recognition and home-country control (for purposes of supervision), the objective was to ensure the fullest possible degree of cross-border competition subject to adequate supervisory oversight. Allied with the Capital Liberalisation Directive of 1988, which for most countries came into effect in 1990, the prospect offered was a sharp increase in competition based on both enhanced rights of establishment and increased cross-border trade. The fact that virtually all of the policy goals embedded in the Banking Directives have since been implemented through domestic legislation in most of the countries of the European Union would also seem to augur well for a heightened level of international competition.

The changing role of the state with respect to pensions is best treated as an aspect of demographic change. State reliance on unfunded pension schemes in Europe is being increasingly seen as unsustainable given the ageing of the population. Legislation in France was proposed to allow 14 million private sector employees to "top up" state-sponsored pensions with equity holdings, although the decree to bring it into effect has not yet been published. However, much more activity of this sort does seem likely to follow, and the development of capital markets in Europe (and of nonbank financial intermediaries which deal actively in such markets) will be stimulated accordingly. Moreover, this is not the only implication of a European population which is growing older on average. In such a society, particularly if allied with continuing increases in national income and wealth, the marketing emphasis must shift away from financial products directed to the young poor (consumer credit and mortgages) to asset management services for the old rich. The latter set of clients are likely to be both more knowledgeable and more demanding. This combination of forces is not likely to be to the advantage of traditional banking liabilities since the rates of return they offer

21 See Moody's Investors Service (1997).

22 For an overview of these early developments see Gual and Neven (1993) and Chrystal and Coughlin (1992).

23 This trend is not unique to Europe. As Llewellyn (1996), p. 158, notes: "... the universal trend is that public policy priorities have shifted towards enhancing banking efficiencies through competition and in the process public policy has become less protective of the banking industry". 
must be relatively low. ${ }^{24}$

A further underlying force for change is an increased concern for shareholder value. This objective has been emphasised for years in the English-speaking countries and is increasingly manifested in such forms as continuous cost-cutting (even in "good times"), share buybacks and the recent phenomenon of demutualisation of mutually owned financial firms. ${ }^{25}$ The rates of return on capital in continental European banking have been below those of their competitors for many years, but there has thus far been little pressure from shareholders for that to change. In part, this is because government unwillingness to countenance hostile takeovers has permitted small groups of long-term shareholders to effectively control the company. In part, it is because other current shareholders have remained quite passive. ${ }^{26}$ However, there are emerging signs that this culture is beginning to change. ${ }^{27}$ With respect to hostile takeovers, these are increasingly in evidence in continental Europe and governments seem somewhat more (although not wholly) comfortable with the concept. As for the problem of passive shareholders, increased ownership of bank shares by pension and other funds, whose own performance is being assessed by the ultimate owner of those funds, will be of increasing importance. ${ }^{28}$ The clear trend towards the cross-listing of European shares on US exchanges will also work strongly in the same direction.

A final force for change in European banking will be the introduction of the euro. A coauthor and I have argued in an earlier paper ${ }^{29}$ that the euro will be not only a direct cause of but also a catalyst for change in response to the underlying forces described above. The most important aspect of the former effect is that the introduction of the euro will stimulate the growth of a much larger and more liquid securities market in Europe. The speed with which this will happen will depend in large part on the efforts made by governments to ensure that it will happen. Securities markets can then be

24 A further reason why current low yields might be considered "derisory" by investors is that Europe has just come through a long period of disinflation. Through those years, both nominal and real rates have been high if generally falling. If investors also suffer from money illusion, the phenomenon of nominal rates being thought "too low" would be further strengthened.

25 In the United Kingdom, there has been almost total demutualisation of traditional building societies. In the United States a number of insurance companies have transformed themselves into private companies, the most famous of which is surely the Prudential Insurance Company. The same thing is happening in Canada.

26 To use the terminology of Davis (1996), pp. 82-5, three forms of possible corporate governance have been lacking: market control via equities (the threat of hostile takeovers); direct control via equities (current shareholders being more demanding); and market control via debt (leveraged buyouts forcing a greater concern for efficiency to ensure debt service).

27 See Dickson (1998): "Companies based in Western Europe were obliged by increased competition to consider shareholder value to a greater extent, and also to engage in merger activity". See also House (1998).

28 A famous example has been the ongoing battle between the management of the Union Bank of Switzerland and Martin Ebner's BK Vision Fund, a battle won by the latter to his considerable profit.

29 See McCauley and White (1997). 
expected to pose a significant competitive challenge to banks offering traditional forms of intermediated credit. ${ }^{30}$

The introduction of the euro may also increase interbank competition to some degree. In particular, a single currency may affect the behaviour of bank customers. A greater capacity to compare rates and fees across borders, without the need to factor in currency considerations, should increase competition among individual products. There will also be increased competition for relationships as multinational firms seek to consolidate treasury operations which were previously spread over many different currency zones. ${ }^{31}$ At the same time, corporations will want to ensure that the financial institution they choose to be their banker will have pan-European capabilities.

A single currency might also help change the behaviour of financial institutions themselves, inducing them to think about the contestability of European and not just national markets. With respect to corporate clients, the extra risk associated with making medium-term loans in foreign currencies will disappear, thus encouraging more international lending. ${ }^{32}$ The fact that potential gains from speculating on currency movements will be reduced should also lead to a greater reliance on credit risk as a source of profits. In turn, this should lead to a heightened appreciation of the need to adequately evaluate credit risk. And with such a methodology in place, the nationality of the borrower should become less important. The need to alter computer systems in anticipation of the euro might also prompt some strategic rethinking of the business functions they support. Both possibilities may, however, be limited by the realisation that corporate banking in Europe is nowhere a very profitable business. The introduction of the euro may even encourage banks to actively seek out retail customers in other countries if they believe that such customers will demonstrate less national bias after the introduction of a common currency. While reducing such prejudices is in fact one of the fundamental purposes of the exercise, it would seem prudent not to expect major changes in consumer behaviour in the near term.

\subsection{Manifestations of underlying forces}

The globalisation of trade in financial services is a by-product of underlying forces like those described above. Technological advances and lower communication costs make a global reach

30 If outstanding bonds of non-investment-grade firms and commercial paper outstanding on non-financial firms were to increase in Europe at the same compound rate as they did in the United States from 1980 to 1996, about one-third of European corporate loans would disappear. The increase in the issue of "below credit grade bonds" in Europe in 1997 has already been quite remarkable.

31 Differing tax regimes in different countries may, however, impede such consolidation.

32 However, it is argued in McCauley and White (1997), p. 24, that this may not currently be a significant impediment to such business; lenders can always obtain medium-term foreign funds using cross-currency basis swaps at relatively modest cost. 
more practical, while deregulation has opened up many new markets. The recent international agreement on trade in financial services, under the aegis of the World Trade Organization, seems likely to enhance such pressures. In the European context, the practical implication is that continental markets may become more contestable, not only to other continental banks also having a universal banking character, but also to institutions (both financial and non-financial) incorporated in English-speaking countries and operating continent-wide with a single "passport". Experience in other countries indicates that an increase in the share of business done by foreign banks lowers profitability, in spite of an associated reduction in overhead expenses. ${ }^{33}$ Indeed, Canadian experience shows that this may happen even when foreign banks fail to increase market share, as cosy cartel-like relationships are shaken up. ${ }^{34}$

In the area of global investment banking, the principal competition to continental European banks is coming from the United States. ${ }^{35}$ In a recent evaluation by Morgan Stanley Dean Witter (1998) only Credit Suisse, United Bank of Switzerland and Deutsche Morgan Grenfell were ranked even as "Tier Two" banks ${ }^{36}$ after four American firms: Merrill Lynch, Goldman Sachs, J.P. Morgan and Chase Manhattan. Moreover, the competition from this source is strengthening further as the influence of Glass-Steagall wanes and US mergers increasingly combine world-class producers of financial products with huge distribution networks. ${ }^{37}$ A recent article in The Banker (see Owen (1997)) indicated that even the introduction of the euro might favour US financial institutions since they had "pan-European capabilities and mindset" in greater measure than universal European banks.

There is also likely to be growing competition from global banks at the retail level. Citicorp and HSCB Holdings are generally acknowledged as having the most advanced strategy for global expansion. Indeed, the former is known to have already been successful in attracting the business of high-income German investors away from German banks. Moreover, in virtually all areas of the local banking business (comprising operating services, asset management and consumer services) other powerful but non-continental competitors are also emerging. One impetus behind this

33 See Claessens et al. (1998). See also Freedman and Goodlet (1998), pp. 7-9.

34 See Freedman and Goodlet (1998), p. 8.

35 See Morgan Stanley Dean Witter (1998), p. 61: "What distinguishes [US banks] are leadership in global advisory and equity businesses, state of the art products, vast placement power, a strong US base and significant international earnings streams, and strong client relationships".

36 Note that Barclays and Natwest both withdrew from full-service investment banking in 1997, reflecting in part low rates of return on that business compared with retail banking. The future intentions of Deutsche Bank are also not wholly clear in light of recent developments in its North American office and the decision to fully integrate Morgan Grenfell and transfer control back to Frankfurt.

37 In 1997 alone the following mergers occurred: Morgan Stanley-Dean Witter, Banc One-First USA, Bankers Trust-Alex. Brown, Salomon Brothers-Travelers, and Merrill Lynch-Mercury Asset Management. In 1998 (to 14th April) we have had announcements of megamergers between: Citicorp and Travelers Group; NationsBank and Bank of America; Bank One and First Chicago. 
is the sharp difference in productivity levels across countries ${ }^{38}$ which means that the "arbitrage possibilities in retail are huge". 39 If customers become increasingly willing to abandon local branches in favour of electronic transactions, the competition provided by global banks could intensify markedly. This process will be further enhanced to the extent that global companies succeed in their current efforts to develop a single brand name that will "inspire trust and affection" in the various countries of continental Europe. ${ }^{40}$

\section{Securitisation and the associated growth of non-bank financial intermediaries (life}

insurance companies, pension funds, mutual funds, etc.) are another by-product of the underlying forces described above ${ }^{41}$ and will pose another challenge to continental European banks. Indeed, there is a symbiotic relationship between these two developments in that savers will increasingly wish to pool risks and raise returns by investing in the liabilities of non-bank financial institutions, which in turn will need to invest in assets (securities) with known degrees of risk. Technological developments have supported pooling processes of this kind, as described above, and have sharply lowered the costs of securitisation of bank-originated credits. The fact that new issues of public sector securities in Europe may also be reduced, in view of ongoing fiscal retrenchment, likewise supports the increased securitisation of private sector debt. Underlying demographic patterns in Europe and increased reliance on funded private pension schemes (as opposed to traditional unfunded public schemes) will also reinforce these trends, as will the introduction of the euro, which should in principle override existing national restrictions which currently force investment funds to invest "at home". The increased capacity, and the growing desire, of non-bank financial institutions to provide many of the services normally ${ }^{42}$ provided by banks is another competitive factor to be taken into account. ${ }^{43}$

Finally, the same underlying forces are increasing competition from unregulated "non-

banks" in the provision of banking services. Indeed, many large corporations are increasingly

38 See Gros and Lannoo (1996).

39 Lowell Bryan, consultant at McKinsey Corporation, quoted at a seminar, November 1997. McKinsey estimates that global profits from retail financial services will rise from \$350 billion in 1997 to $\$ 770$ billion in 2007.

40 See Martin (1998). It is notable that in the last few months, Morgan Stanley Dean Witter has reverted to the name Morgan Stanley and Deutsche Morgan Grenfell has become plain Deutsche Bank. Citicorp and American Express have also been actively promoting their brand identity on a global scale and the newly formed Citigroup clearly intends to do so.

41 For an excellent and comprehensive overview of the factors encouraging the growth of non-bank financial intermediaries and the implications of this trend, see Davis (1996).

42 For example, money market mutual funds in the United States offer chequing privileges and, in principle, funds can be withdrawn without delay. In a crisis, of course, this would not be possible unless such funds were given access to the central bank as lender of last resort.

43 Davis (1996) states that some economists believe that "all of banks' functions could be taken over by institutions such as pension funds, life insurers and mutual funds operating via securities markets" (p. 91). He then goes on to provide some counter-arguments to this extreme position, referring in particular to the banks' continuing advantage in collecting asymmetric information about small and medium-sized enterprises. 
carrying out their banking business "in-house" (e.g. Volvo, BP and Renault). In the United States, General Electric and Ford are now two of the largest financial services companies, and the former is expanding vigorously into Europe (and Japan) in direct competition with local providers of financial services. In the United Kingdom, Sainsbury, Marks and Spencer and Tesco are all now taking deposits as well as making loans to their retail customers. Specialised companies are also targeting the markets for credit cards, mortgages and the leasing of certain kinds of equipment. Here again, increasing inroads are being made into European markets. The central point is that the fixed costs of entering these markets have come down with advances in technology and many financial services can now be produced by specialised providers very efficiently and at low cost. The fact that many of these companies have extremely well-known brand names gives them a further competitive advantage. Whether unregulated entities have a competitive advantage simply because they are unregulated is moot given that regulation of banks in the past was often directed to maintaining the rents associated with cartel-like behaviour. It is the case, moreover, that the costs of regulation are to some degree offset by certain benefits (e.g. access to lender of last resort facilities).

Another area where competition seems set to increase is electronic payments processing and the provision of services over the Internet. This is a global phenomenon that will certainly affect continental Europe. Non-financial firms that control communications networks, and the gateways to them, could set themselves up as "brokers" directing customers to the most suitable product for them. The loyalty of the customer would increasingly be to the broker rather than the ultimate producer of the product. At the very least, this process will squeeze margins of traditional financial service providers. At most, these non-financial firms could use the information made available to them through data-mining technology to design new products themselves ${ }^{44}$ to compete with products from traditional financial service providers. Moreover, in this virtual world where concerns about security are naturally heightened, the possession of a brand name inspiring confidence will become ever more important as a marketing tool. This may further encourage non-banks to contemplate new forms of competition against European banks whose brand recognition does not tend to be very high.

\subsection{Multiplicative effects and the bottom line}

It has been analytically convenient above to treat the various forces for change separately. This should not blind us to the fact that the interactions among them are perhaps even more important, leading to dynamic processes that may be hard both to predict and to control. The accelerating pace of both technological change and deregulation (the demise of Glass-Steagall in the

44 See Crockett (1998): "The threat is especially serious in those areas where marketing and flexibility of service are vital while liquidity provision is secondary". 
United States, the "Big Bang" in Japan and the introduction of the euro) implies that there may be a heightened probability of observing such interactive processes in the near future.

By way of example, there are important forms of interaction between technology, competition and deregulation. ${ }^{45}$ New technology allows firms (both old providers of financial services and new entrants) to sidestep regulations and this in turn could lead to pressure for deregulation to level the playing-field. ${ }^{46}$ Deregulation in turn leads to more competition, which, in the financial services industry, leads to a still heavier reliance on technology to gain a competitive edge. As competitive pressures mount, banks may find that their credit ratings fall below those of their customers, providing a further boost to securitisation and causing further loss of profits for many traditional intermediaries. This in turn may lead to more pressures for a level playing-field, more investment in technology, and so on.

Another form of potential interaction is the way in which technology lowers the costs of obtaining and processing information, as well as allowing non-banks to provide services previously only available at banks (e.g. payment services). Such developments make banks less "special", implying either less need for their regulation or a greater need for regulation of those non-banks providing similar services. Should there be less traditional regulation of banks, this would imply a greater reliance on market discipline and more disclosure of information to the public at large. More transparent accounting and an increased role for rating agencies tend to further erode banks' monopoly power over asymmetric information and further increase competitive pressures. The "bottom line", summarising the effects of all the above influences, is in fact the bottom line: bank profits in continental Europe are already under pressure and there are some grounds for believing that these pressures could intensify sharply and quickly.

\section{Broad forces impeding change in continental European banking}

As will be further documented below, the numerous forces for change in the competitive status quo have not thus far had significant effects on the face of continental European banking. Thus, one is immediately challenged to identify the offsetting forces that have acted to maintain the competitive status quo. Some of these forces have their roots in time-specific circumstances, others are institutional in nature, while still others are cultural. As one moves from time-specific to cultural considerations, the likelihood of near-term change obviously declines.

45 The way in which the introduction of the euro might accelerate deregulation and the dismantling of national barriers to trade in financial services is another form of interaction dealt with in McCauley and White (1997), p. 23.

46 It must be admitted that another possible response would be an increase in protectionism. Indeed, Mario Monti recently warned that the increased competitive pressures arising after the introduction of the euro might have this effect. I am assuming this will not happen, but it is a very important assumption. 


\subsection{Time-specific issues}

A number of the underlying forces for change identified above are of relatively recent origin, in particular the heightened concern for shareholder value and the forthcoming introduction of the euro. These influences can be expected to grow as time passes. The fact that certain manifestations of the underlying forces have recently become much more evident (globalisation and the trend to securitisation) may indicate that a period of more rapid adaptation in continental European banking is now imminent. The euro could be a catalyst for such changes.

Other factors impeding change will also disappear with time. For example, the degree to which new information technology makes retail banking more contestable has been limited by the "conservatism" of European households, but this is already changing. ${ }^{47}$ Zimmerman (1995) makes the case that major financial restructuring, especially that having an international dimension, has been affected in recent years by the slow growth of the major continental economies. This has tamed "animal spirits" and, by exacerbating the problem of doubtful loans, has put further constraints on the availability of capital (at the level of the firm), already in short supply relative to new and more onerous regulatory standards. He argues that when the continental European economy begins to recover more forcefully, new initiatives might then become more common. This hypothesis is not inconsistent with more recent experience; the upturn in the European economy through to mid-1998 has been accompanied by a heightened level of financial restructuring. A further consideration is that "scarce" management time in European banks may have been preoccupied with the success of large internal investments in market risk models. ${ }^{48}$ Once these are completed, the attention of senior management can turn elsewhere.

\subsection{Institutional and cultural impediments to change}

Within individual continental countries, there are many institutional impediments to rapid change in the financial sector. These impediments were generally introduced with a view to fostering financial stability, even if sometimes at the expense of financial efficiency. Cartel-like arrangements, often with associated economic rents, were thought desirable because the fear of losing the "franchise value" of such a firm would inhibit excessive risk-taking.

Historical experiences referred to earlier indicate that international competition, or at least contestability, could serve to destabilise such arrangements. Unfortunately, the institutional

\footnotetext{
47 The number of PCs per household is much lower in Europe than in the United States as is the number of Internet hosts per 1,000 inhabitants. See OECD (1996). However, the growth rates in Europe are significantly higher.

48 The impetus for this can be found in Basle Committee on Banking Supervision (1995).
} 
impediments to international competition in continental Europe remain quite severe. The legal, tax, regulatory and supervisory frameworks within which financial institutions have to operate continue to differ in significant ways across the various countries in the European Union. ${ }^{49}$ Different accounting and reporting procedures, "technical standards" and employment practices also work in the same direction. Such differences in themselves make international competition less appealing in that it becomes more complex. ${ }^{50}$ Moreover, such differences increase uncertainty about what might happen in a foreign country under exceptional circumstances. ${ }^{51}$ The effect of such differences on competition will evidently be all the greater if national practices have the effect (whether intentional or unintentional) of supporting national enterprises.

A particularly important impediment to change in Europe is labour laws which provide significant protection to workers against job shedding. Moreover, such laws have in some cases been reinforced by special legislation or regulations directed specifically to the banking industry. ${ }^{52}$ The purpose of such initiatives has generally been to enhance further the rights of existing workers, not only directly by constraining management initiatives, but also indirectly by forbidding certain forms of competition. While the process of deregulation referred to here will eventually have some effect in this area as well, this process is likely to be slow given a high level of unionisation in the banking industry and a significant degree of state involvement as well. In the interim, the preferred method of laying off staff seems to be through attrition, which is a slow and often costly process.

In a number of countries, there also continue to be restrictions on the kinds of financial products which can be offered, ${ }^{53}$ which clearly reduces the incentive for new entrants to compete by offering financial products developed in their own countries. Many of these differences have been allowed to remain given the existence of an opt-out clause in the Second Banking Directive which can be invoked in the interests of the "general good" (ostensibly consumer protection). A recent study

49 For a fuller documentation of these differences, see Economic Research Europe Ltd. (1996), Barth et al. (1996), Zimmerman (1995) and Chrystal and Coughlin (1992).

50 A particular impediment to international acquisitions is the often extremely complex corporate structure of the targeted firm and the need to buy it all. As domestic firms restructure and unbundle, international deals could become easier. This is another example of the interactive effects referred to in Section 2.3 above.

51 Suppose, for example, a bank in one country wished to purchase a bank in another country which had a partially owned subsidiary that was in difficulties. To know the possible effect of this on the value of the company as a whole would demand a full understanding of bankruptcy procedures, tax law, labour law, etc.

52 For example, in France there are the decrees of 1936 and 1937. In Italy, the constraints imposed by existing law meant that a special law was recently needed to allow the restructuring of the Banco di Napoli.

53 In France, for example, it is still not permitted to pay interest on sight accounts. Barclays attempted to introduce such a product but was forced to drop it and eventually withdrew from retail competition in France. France and Belgium also insist that all mortgage contracts have an early repayment clause, whereas this is not even an option in many EU countries. In France, until quite recently, banks were not allowed to open on weekends or evenings. Telephone banking was also prohibited. In the Netherlands, door-to-door selling of financial services is not allowed. 
(1996) commissioned by the European Commission highlighted the extent to which this clause could be, and indeed was being, used to stifle foreign competition. While the Commission has in recent months issued a "communication", to interpret existing law so as to remove uncertainties and encourage competition, it remains to be seen whether this latest move will have much effect. ${ }^{54}$

Allied to the influence of these remaining institutional differences has been uncertainty about how national governments might react to certain cross-border initiatives. Takeovers of large national banks by foreigners is a traditionally sensitive issue in most countries, both inside and outside Europe. With the state itself being so active in the banking business in many countries, the objectivity exercised in the use of its powers might be even further questioned. Restructuring of banks leads almost inevitably to job losses, which can be politically sensitive in themselves. When the initiators of such actions are foreign, that political sensitivity is likely to be even higher.

Such concerns reflect the perception of a continuing cultural bias in most countries towards their own citizens and institutions. Different national languages, different national practices and simple inertia on the part of customers are other factors impeding cross-border competition which could prove more difficult to overcome. A simple but striking observation supporting this view is that arrangers of syndicated loans (see Table 8) tend to have the same nationality as the borrowing entity, regardless of the currency in which the loan is being made. ${ }^{55}$

\section{Recent developments and the balance of forces}

In Section 1 above, a number of salient facts about the continental banking industry were presented as prima facie evidence indicating that the level of efficiency is not currently high. In this section, the focus is on recent changes in the industry in response to the forces just described. Three sets of evidence are considered: changes in the prices of financial services, changes in banking practices at the level of the firm, and changes in the banking industry at the inter-firm level. The broad impression given is that change is beginning to accelerate but has really only just begun. In the final section of this paper, attention is drawn briefly to some issues of public policy that might arise in this process.

As to changes in the prices of financial services, a 1996 study ${ }^{56}$ carried out under the auspices of the Banking Advisory Committee of the European Union is the most exhaustive

\footnotetext{
54 See Tucker (1997). The same article described retail banking as "the single market's least successful sector".

55 In contrast, lead managers for the underwriting of bond issues are chosen because they share the nationality of the currency being borrowed. This effect is more important than the lead underwriter and the borrower sharing the same nationality. See McCauley and White (1997), p. 8.

56 See Economic Research Europe Ltd. (1996).
} 
investigation to date. Directed to assessing the effectiveness of the "single market programme", it broadly concluded that the impact had not so far been very significant. Nevertheless, some important changes were indeed discernible. In some of the countries that were most heavily regulated to begin with, the costs of some services had fallen markedly, and the margins on corporate loans seemed to be under pressure almost everywhere. The price of credit cards had also dropped sharply as had the interest rate differentials across countries. In contrast, the study indicated that there had been little narrowing of the substantial price differences across countries ${ }^{57}$ for consumer loans, the use of current chequing accounts, personal equity transactions and the cross-border transfer of funds. If one measure of untrammelled international competition is that the law of one price prevails, then on this evidence continental European banking remained far from this model as recently as 1996. The necessity to cut prices further in an increasingly competitive environment implies that other adjustments to maintain profits will have to be even greater.

Turning now to changes at the level of the firm, the above impression is generally confirmed. Changes directed to maintaining and increasing profits are occurring but generally only slowly. Evidence presented below refers to changes with respect to (1) rationalisation and costcutting; (2) new business orientations; and (3) increased risk-taking. With respect to the first two sets of initiatives, significant impediments to progress can also be identified. One danger arising from this is that excessive reliance may then be placed on the third possibility, increased risk-taking. This is pertinent to the discussion of public policy issues in Section 5.

Rationalisation and cost-cutting can be achieved in various ways. One way is to reduce the number of branches and to centralise certain services. Table 9 indicates that this process is generally less well advanced in continental Europe than elsewhere, ${ }^{58}$ though significant changes have taken place in both Belgium and the Netherlands. In the former case, however, branch density continues to be very high. Another possibility is to consolidate back offices, with a view to increasing efficiency, and/or outsource the provision of certain services. Such initiatives are well advanced in North America, ${ }^{59}$ with most US and Canadian banks having outsourced all or part of their routine processes. Indeed, J.P. Morgan's recently announced "Pinnacle Alliance Arrangement" seems set to

57 These cross-country differentials were noted in an earlier study by Price Waterhouse (1988). It compared the prices of financial products in individual European countries with the prices charged by an average of four "low-cost" producers. By this standard, it found that prices in many countries were $25 \%$ to $30 \%$ "too high".

58 The fact that the number of branches in the United States is still growing probably reflects the effects of the repeal of the McFadden Act whose purpose was to impede inter-state branch banking. Another important factor is the spread of very small branches in supermarkets across the United States.

59 See Freedman and Goodlet (1998), pp. 2-3, who note how widely outsourcing is used in other industries, e.g. airlines which outsource maintenance, cleaning, reservations, accounting, etc. 
raise the possibilities here to an entirely new level. ${ }^{60}$ Table 10 provides evidence with respect to costcutting overall. While employment levels have come down relatively slowly from previous peaks in continental Europe, staff costs as a percentage of gross income have declined more rapidly in some countries. As noted above, labour laws in many continental European countries constitute a significant impediment to cost-cutting through the shedding of labour in the banking sector.

Another avenue for increasing profits is to develop new business orientations, implying change to the product range, the delivery systems and the organisational structure of the bank. With respect to changes in the product range, a number of continental European banks have taken aggressive steps in recent years to move into new lines of business. The problem, however, is that everyone cannot do the same thing and still hope to see an increase in profits. This is obvious where the product or service being sold is essentially a commodity, indistinguishable from company to company. However, there may also be problems with deciding to produce services which are highly customised for individual clients. Such products often involve very expensive labour inputs (e.g. financial engineering) which squeeze profits from the side of costs. Moreover, as technology advances, even customised products may become contestable.

The difficulties faced by European banks that have moved into global investment banking have already been referred to. Asset management is another area where banks hope to extend their reach, and are well placed to do so given their still strong relationships with customers. However, it will demand the introduction and aggressive marketing of the kinds of high-yielding funds which customers seem to want, while at the same time dealing with competition from those already well entrenched in that business. ${ }^{61}$ Recent mergers between banks and insurance companies in Europe are a step forward in this regard, building on the recognition that the skills needed for an effective asset management business can be found within the life insurance industry. Private banking is another area where continental banks from EMU countries are trying to expand, but such customers will almost surely prefer banks with global reach. In this area, the Swiss banks are formidable competitors. ${ }^{62}$

There are also potential profits in redesigning delivery systems and in introducing new organisational models. With respect to the former, McKinsey's sees "the radical rationalisation of

60 An "alliance" involves a set of agreements among participating companies each of which then outsources common processes to the member of the alliance that can carry it out most efficiently. This lowers costs, implies management can focus more on core business issues, and provides the potential to attract world-class talent (especially in the IT area) to run such outsourced services at very high volumes.

61 The new United Bank of Switzerland will have $\$ 400$ billion of assets under management, three times as much as Deutsche Bank.

62 The newly formed Credit Suisse Private Banking already has 50 offices in Switzerland and 40 more abroad covering every significant financial market. According to Morgan Stanley (1998), "In our opinion it would take competitors up to a couple of decades to replicate CSPB's competitive edge in global private banking". 
traditional branch capacity, the tailoring of remaining branches to target customer needs and the migration of sales and services to non-physical distribution channels". The essence of this new form of banking is to profit from using new technology and associated databases to offer different services in different branches to match the profile (and unstated wants) of the particular group of customers. While alternative distribution processes are beginning to appear in European banks, ${ }^{63}$ a fundamental rethink of the role of branches does not yet appear to have begun. As for new organisational models, a currently fashionable idea is to organise the business along product lines (supported by specialised IT and compensation systems and strong sales support) so that managers' performance can be more easily evaluated. ${ }^{64}$ Reorganisations along such lines have recently been seen at some larger European banks with global pretensions, but elsewhere the traditional monolithic model continues to prevail.

A third and less welcome possibility is that continental European banks will react to strengthening competitive pressures by taking on increasingly risky business. Such phenomena have been seen regularly in many countries over many centuries ${ }^{65}$ and there are no good reasons for assuming it could not happen in Europe. The likelihood of such behaviour will be increased if banks focus excessively on the relative size of their portfolios (rather than profits) and/or have low capital ratios, conditions which might in fact apply to a number of continental banks. ${ }^{66}$ Indeed, it is already a fact that the Banking Commission in France had last year to warn a number of its largest banks to cease making loans at margins significantly below threshold levels specified by the Bank of France. ${ }^{67}$ It is also a fact that the continental banks have not been immune from other forms of excessively competitive behaviour which have contributed to the huge expansion in international lending in recent years. Indeed, continental European banks already have a collective exposure to Asian borrowers which is virtually equal to the exposure of Japanese banks, ${ }^{68}$ and much greater than the exposure of

63 For example, an increasing number of banks are now offering telephone banking services. On-line banking is also expanding rapidly. Supermarket branches have also begun to appear in Germany; Commerzbank has opened eight branches and has plans for 22 more. By way of comparison, however, half of all California's bank branches are in supermarkets. See Rhoads and Ascarelli (1998).

64 In the limit, the product line could even be spun off as a separate company. This may sometimes be the best strategy to compete head on with unregulated providers of financial services.

65 As a recent example of such processes, consider what followed after US banks experienced large losses on loans to emerging markets in the early 1980s. Banks then introduced sequentially a whole host of essentially new and risky activities: a massive extension of loans for LBOs, property speculation, proprietary trading and finally loans to emerging markets again.

66 See McGrath (1997). Banks "gambling for resurrection" might have adequate capital given accepted accounting conventions, but insiders might well know that bad loans were inadequately taken into account in such calculations.

67 See Jack (1997).

68 BIS statistics indicate an exposure of about $\$ 118$ billion for each group as of June 1997 (see BIS (1998)). A somewhat different way of increasing foreign exposure has been sought by Banco Santander and Banco Bilbao Vezcaya of Spain. They have respectively invested 32\% and 23\% of their total equity in banks in Latin America (IBCA, July 1997). 
North American banks. Moreover, this exposure was apparently the result of a strategic decision by many banks to "target middle Asia" in response to declining margins at home. Finally, greater risktaking need not be confined to accepting lower-rated credits. Proprietary trading in underlying and derivative instruments also offers enormous potential for taking on market risk for those tempted to do so. ${ }^{69}$

Turning finally to inter-firm developments, mergers and acquisitions (M\&As) tend to be driven by similar objectives to those which motivate intra-firm adjustments. There are plausible grounds for believing arguments in favour of economies of scale and scope in the provision of financial services. However, there are plausible counter-arguments as well. With respect to economies of scale, rationalising branches and back offices has obvious appeal but there may be offsetting managerial costs and complications if a firm becomes too large. Consolidating IT infrastructures might also seem to provide opportunities for reducing average fixed costs, although the premise underpinning this conclusion is that IT services are produced in-house rather than bought in, and the costs and dangers associated with managing the transition to a single IT system must also be taken into account. As for enhancing revenues, it is often contended that large amounts of capital are needed to underwrite large deals in the international investment banking business. This is true, but can only be a motivation for those few firms with global aspirations. Finally, it is sometimes argued that the capacity to offer a wider product mix will also enhance revenues and profits. Again there is an element of truth in this argument, but it does presuppose a desire for one-stop shopping in financial services, which was questioned above. Fully exploiting these new possibilities will also demand that newly merged entities recognise all the possibilities opened up by a shared client list, which may not be easy.

In the face of conflicting theoretical arguments about the advantages of M\&As, those contemplating such action might turn to the empirical literature. Unfortunately, they would find it equally inconclusive. For example, in the 66th Annual Report of the BIS (pp. 89-90) it is noted that "upgradings of new entities have far outnumbered downgradings" and the share prices of both firms have often outperformed the banking sector taken in aggregate. In contrast, the Report also notes that, in the United States at least, the share prices of bidding companies have on balance underperformed relevant stock indices, indicating that too much was paid for the purchased shares in the first place. One must also note that even a positive market response to an announced merger is no guarantee that the projected profits will actually materialise. On the basis of a sample (1984-94) of 200 banking sector acquisitions in the United States, Craig (1997) notes that there was a strong tendency for

69 Recall that the actual failure of Bank Herstatt was catalysed by foreign exchange losses on risky transactions prompted by losses elsewhere. 
employment to subsequently rise, not fall, in both the acquiring and acquired institutions, though he makes no specific reference to the effects on profits.

It is also a fact that most of the work on M\&As in banking draws on US experience. Reviewing this, Borio and Tsatsaronis ${ }^{70}$ conclude: "Unfortunately existing evidence has on balance tended to indicate that M\&As are not an effective mechanism for improving the profitability and efficiency of the companies involved". More recently, Vander Vennet ${ }^{71}$ has conducted two studies based on European data from 1988 to 1993 which lead him to conclude that some M\&As add value while others do not. He concludes that domestic mergers of equals, as well as cross-border majority acquisitions, lead to increases in profits and efficiency. However, domestic acquisitions of "small by big" (as well as participatory arrangements) fail to do so, perhaps because the acquisitors have been more focused on growth and size than on profits. Obviously, there is no reason why past errors with respect to focus would have to carry over into the future but, by the same token, there is no reason why they might not.

Whatever the evidence might indicate, there has been a sharp expansion of M\&A activity in the United States in recent years (see Table 11). Moreover, there have been further significant declines in staff costs, as a proportion of operating costs, to the lowest levels recorded among the countries considered in Table 10. Even if there are not yet comprehensive studies supporting the view that the M\&As contributed to this outcome, anecdotal evidence certainly does so. ${ }^{72}$ Moreover, a significant number of US banks have used M\&As to position themselves as major super-regionals with a reasonable chance of becoming a truly national player. Indeed, many of these banks have chosen names which clearly reveal their aspirations. ${ }^{73}$ The fact that US M\&A specialists are currently playing a very large role in advising European financial institutions ${ }^{74}$ implies that these US experiences (presumed successful) will not be overlooked.

In continental Europe, the trend to M\&As is less well advanced although, as is indicated in Tables 11 and 12, there has recently been a sharp escalation in such activity. Moreover, consolidation has gone further in some countries than in others, being classified by Moody's as "meaningful" in the Netherlands and Italy (commercial and savings banks) but "still behind" in

\footnotetext{
70 See Borio and Tsatsaronis (1996) and BIS (1996).

71 See Vander Vennet (1995 and 1997).

72 For example, the Chase-Chemical merger was expected to generate $\$ 1$ billion of savings. The takeover of Barnett's by Nation Bank led the latter to predict a 50\% cut in costs at Barnett's without any significant loss in revenues.

73 In the eastern region the dominant bank was "NationsBank"; in the central region, it was "Bank One" and in the west, it was the "Bank of America". As noted above, each of these banks has recently been involved in a merger designed to provide "national" status.

74 See House (1998).
} 
Germany, France, Belgium, Spain (savings banks) and Italy (in the case of cooperative banks). ${ }^{75}$ Indeed, the same source refers to German initiatives to date as "just starting" and French efforts as "timid". This former judgement stands somewhat at odds with the assessment recently put forward by the Bundesbank, ${ }^{76}$ which emphasised ongoing efforts to merge a number of public sector banks, and the recently announced merger of two large private banks (Bayerische Vereinsbank and Bayerische Hypotheken- und- Wechsel-Bank) to form the second largest bank in Germany.

Consideration of recent M\&As in Table 12 indicates that most of the activity has been between domestic banks. This is not surprising. First, domestic mergers normally imply the greatest scope for overlaps and associated cost-cutting. Resti (1996) has identified certain "clusters" of European banks which share such common characteristics as product mix, source of profits, recent profit experience, etc. He finds that there is a strong correspondence between these objectively identified "clusters" and national groupings. As a more practical example of the possibilities, albeit involving a merger of equals (recall Dermine's evidence above), the management of the new United Bank of Switzerland estimates that 13,000 of 56,000 jobs worldwide will be lost, with 7,000 of those in Switzerland. This amounts to a cut of $30 \%$ in operating expenses and most analysts seem to believe it is feasible. Second, domestic mergers also avoid many of the uncertainties which seem likely to emerge whenever business is extended over international borders, whether in the form of M\&As or in other ways.

Table 12 indicates that there has also been a recent but less significant trend towards M\&As involving domestic banks and non-bank providers of financial services, in particular insurance companies (bancassurance). However, it is also the case that such ventures have been around for a long time, implying that there may be less (if still significant) scope for new ventures. Fortis, the Belgian-Dutch group, has combined banking and insurance for years, while ING has been doing so since the early 1990s. Among more recent examples would be the merger of Credit Suisse and Winterthur (both Swiss) and INA and Banca Nationale del Lavoro (both Italian). One important advantage of such developments is that bank branches can be used to distribute standard insurance products much more cheaply than can be done through salespeople. Another is that banks wishing to expand their expertise in asset management can find experienced talent in the insurance business.

However, one question which arises almost immediately is whether these obvious advantages might not be better achieved through a cooperative process which is much less "heavy" than a corporate merger. Mergers of banks and insurance companies bring together people of very

75 See Moody's (1998), p.23.
76 Reported by Reuters, 18th March 1998: "Buba sees bank consolidation speeding up after EMU". 
different professional cultures, ${ }^{77}$ which can prove difficult. At the very least, and this in fact seems to have been the pattern to date, M\&As between big banks and small insurance companies might be favoured to avoid the broader and still thornier question of whose culture will dominate.

As implied above, cross-border M\&As in banking have been still less common in continental Europe. Indeed, in the countries considered in this paper, the only significant event last year was ING's (Netherlands) takeover of Banque Bruxelles Lambert (Belgium). While there have been many rumours of other such international M\&As, they have yet to materialise. Given the advantages of domestic mergers listed above, it seems likely that the principal players in such international mergers will be companies that have finished exploiting the possibilities domestically. This implies that the names of Dutch, Swiss and Swedish banks may come increasingly to the fore. Finally, and for the sake of completeness, cross-border bancassurance M\&As have just begun to appear. Again, Table 12 indicates that Belgian and Dutch entities have been at the centre of these developments.

\section{Conclusions and some implications for public policy}

The principal hypothesis of this paper is that competition in continental European banking may be about to increase significantly. This raises many issues of public policy, only three of which are briefly mentioned here. The first has to do with efficiency in banking, the second with prudential issues (crisis prevention) and the third with crisis management.

With respect to the efficiency question, there will have to be further consolidation in European banking. However, in some political quarters there will be strong opposition to this on the grounds that undue concentration will lead to oligopolistic behaviour. Similar concerns have recently been expressed in the face of proposed banking mergers in Canada, the United States and Australia. In evaluating such agreements, the public sector must keep clearly in mind the concept of contestability and the likelihood that excessive profits in domestic banking might quickly lead to competition from banks abroad. This would seem all the more likely in the single economic space of a united Europe.

Prudential issues are closely related to considerations of efficiency. As competition heats up, capital must be used more efficiently. This clearly involves a withdrawal of labour input and most probably some consolidation of capital within the industry as well. In some cases, capital might have to be withdrawn from the industry as a whole on the grounds that it can be employed more profitably elsewhere. Restructuring of this sort could proceed quite smoothly, but there are also reasons to fear a

77 For example, risk management in the banking business is dominated by concerns about asset characteristics. The principal source of concern in the insurance business is the behaviour of liabilities. 
collective weakening of all banks with attendant risks of systemic crisis. Banks themselves, particularly larger ones, may have exaggerated views of their capacity to survive the competitive process and may stay in the fight too long. Heavy investment in technology implies that fixed costs will rise relative to variable costs, making it sensible for some firms to continue operating at a loss for even an extended period of time. Corporate governance may also be inadequate to ensure that management focuses on true restructuring, and associated increases in profits, rather than on simply increasing size or market share. A related danger, given the difficulty of valuing credits, is that a gradual deterioration in credit quality may not be easily detected. Finally, the public sector itself may seek to impede necessary restructuring, whether for nationalistic motives, out of a concern to shelter the labour force, or to achieve other objectives. The worst-case scenario would have many banks in a weakened state "gambling for resurrection" through imprudent loans and other forms of risky business. Recent experiences in many countries and regions of the world, both industrial and emerging, show that the fiscal and macroeconomic implications of weak banking systems can be very significant and should obviously be avoided.

As cross-border financial activity expands in Europe, and as conglomerates increasingly bring together business lines which were previously separate, the task of supervising financial institutions will become more difficult. International cooperation among those supervising banks, investment dealers and insurance companies (and firms comprising all three) will become increasingly important to ensure the health of the financial system. The tendency in some national jurisdictions to consolidate all forms of supervision under one roof, normally outside the central bank, may have certain advantages in this regard but some disadvantages as well. Perhaps the greatest concern has to do with the efficacy of such arrangements given a banking or financial crisis. In such circumstances, the need for immediate and intensive cooperation between national supervisors and national central banks is obvious but it can by no means be assured. In the European monetary union, the task could be rendered more difficult by the fact that supervision remains at the national level and the modalities of cooperation with the supranational European Central Bank remain to be clarified.

Another set of concerns arising from this competitive process has to do with the growth of large conglomerates which might all too easily be considered "too big to fail". The moral hazard problems associated with such a mentality are well known. In contrast, problems could also arise with financial firms that had grown "too big to save". Smaller countries that provided corporate headquarters for such firms could well find the fiscal costs of bailouts both daunting and inconsistent with emerging European standards for sound fiscal behaviour. In sum, if the coming transformation of the banking industry in Europe is likely to present important challenges to the private sector, it seems likely to do so for the public sector as well. 


\section{Tables}

Table 1

\section{Cross-border banking penetration}

\begin{tabular}{|c|c|c|c|c|c|}
\hline \multirow[t]{2}{*}{ Countries } & \multicolumn{3}{|c|}{1996 loans to non-banks } & \multicolumn{2}{|c|}{1997 loans to non-banks } \\
\hline & Domestic credit & $\begin{array}{l}\text { Cross-border } \\
\text { assets }\end{array}$ & $\begin{array}{c}\text { Cross-border as } \\
\% \text { of total }\end{array}$ & $\begin{array}{l}\text { Cross-border } \\
\text { assets }\end{array}$ & $\begin{array}{c}\% \text { change } \\
1997 / 1996\end{array}$ \\
\hline Austria & 255.6 & 6.0 & 2.3 & 7.2 & 20.0 \\
\hline Belgium & 365.1 & 39.8 & 9.8 & 44.0 & 10.6 \\
\hline France & $2,074.1$ & 72.6 & 3.4 & 85.1 & 17.2 \\
\hline Germany & $3,075.5$ & 79.8 & 2.5 & 102.6 & 28.6 \\
\hline Italy & 930.8 & 34.6 & 3.6 & 28.8 & -16.8 \\
\hline Netherlands & 467.6 & 30.3 & 6.1 & 31.3 & 3.3 \\
\hline Spain & 661.6 & 10.7 & 1.6 & 11.5 & 7.5 \\
\hline Switzerland & 494.2 & 25.7 & 4.9 & 28.4 & 10.5 \\
\hline United Kingdom & $1,324.3$ & 145.1 & 9.9 & 151.4 & 4.3 \\
\hline \multirow[t]{2}{*}{ Countries } & \multicolumn{3}{|c|}{1996 liabilities to non-banks } & \multicolumn{2}{|c|}{1997 liabilities to non-banks } \\
\hline & $\begin{array}{c}\text { Domestic } \\
\text { money }\end{array}$ & $\begin{array}{c}\text { Cross-border } \\
\text { liabilities }\end{array}$ & $\begin{array}{c}\text { Cross-border as } \\
\% \text { of total }\end{array}$ & $\begin{array}{c}\text { Cross-border } \\
\text { liabilities }\end{array}$ & $\begin{array}{c}\text { \% change } \\
1997 / 1996\end{array}$ \\
\hline Austria & 177.5 & 5.5 & 3.0 & 5.1 & -7.3 \\
\hline Belgium & 222.1 & 32.4 & 12.7 & 34.5 & 6.5 \\
\hline France & 997.5 & 28.2 & 2.7 & 25.8 & -8.5 \\
\hline Germany & $1,355.3$ & 98.5 & 6.8 & 103.2 & 4.8 \\
\hline Italy & 565.3 & 10.3 & 1.8 & 13.0 & 26.2 \\
\hline Netherlands & 295.4 & 31.3 & 9.6 & 25.3 & -19.2 \\
\hline Spain & 563.4 & 18.4 & 3.2 & 16.3 & -11.4 \\
\hline Switzerland & 337.6 & 79.6 & 19.1 & 79.6 & 0.0 \\
\hline United Kingdom & $1,099.9$ & 128.4 & 10.5 & 132.7 & 3.3 \\
\hline
\end{tabular}


Table 2

Profitability of major banks in 1995 and 1996

\begin{tabular}{|c|c|c|c|c|c|c|c|c|c|}
\hline \multirow[t]{3}{*}{ Countries } & \multirow[t]{3}{*}{$\begin{array}{l}\text { Number } \\
\text { of banks }\end{array}$} & \multicolumn{2}{|c|}{$\begin{array}{l}\text { Return on } \\
\text { assets }^{1}\end{array}$} & \multicolumn{2}{|c|}{$\begin{array}{c}\text { Loan loss } \\
\text { provisions }\end{array}$} & \multicolumn{2}{|c|}{$\begin{array}{l}\text { Net interest } \\
\text { margin }\end{array}$} & \multicolumn{2}{|c|}{ Operating costs } \\
\hline & & 1995 & 1996 & 1995 & 1996 & 1995 & 1996 & 1995 & 1996 \\
\hline & & \multicolumn{8}{|c|}{ as a percentage of total assets } \\
\hline Austria & 4 & 0.38 & 0.36 & 0.59 & 0.49 & 1.79 & 1.72 & 1.79 & 1.80 \\
\hline Belgium & 4 & 0.59 & 0.53 & 0.16 & 0.20 & 1.65 & 1.62 & 1.66 & 1.66 \\
\hline France & 6 & 0.21 & 0.32 & 0.25 & 0.20 & 1.15 & 1.09 & 1.43 & 1.40 \\
\hline Germany & 3 & 0.46 & 0.51 & $0.28^{2}$ & $0.30^{2}$ & 1.55 & 1.37 & 1.87 & 1.98 \\
\hline Italy & 8 & 0.42 & 0.41 & 0.51 & 0.52 & 2.45 & 2.27 & 2.46 & 2.42 \\
\hline Netherlands & 3 & 0.72 & 0.79 & 0.32 & 0.29 & 2.18 & 2.21 & 2.26 & 2.39 \\
\hline Spain & 6 & 0.78 & 0.89 & 0.45 & 0.42 & 2.58 & 2.57 & 2.55 & 2.51 \\
\hline \multicolumn{10}{|l|}{ Memorandum : } \\
\hline United Kingdom & 4 & 1.27 & 1.22 & 0.33 & 0.21 & 2.28 & 2.24 & 2.87 & 2.72 \\
\hline United States & 13 & 1.71 & 1.86 & 0.29 & 0.36 & 3.30 & 3.42 & 3.64 & 3.83 \\
\hline Switzerland & 3 & 0.54 & -0.07 & 0.33 & 0.73 & 1.05 & 0.96 & 2.20 & 2.18 \\
\hline
\end{tabular}

Table 3

Long-term accounting indicators of banks' performance ${ }^{1}$

\begin{tabular}{|c|c|c|c|c|c|c|}
\hline \multirow[t]{3}{*}{ Countries } & \multicolumn{3}{|c|}{ Pre-tax profits } & \multicolumn{3}{|c|}{ Non-interest income } \\
\hline & $1980-82^{2}$ & $1986-88$ & $1990-95$ & $1980-82^{2}$ & $1986-88$ & $1990-95$ \\
\hline & \multicolumn{3}{|c|}{ as a percentage of assets } & \multicolumn{3}{|c|}{ as a percentage of gross income } \\
\hline Austria & 0.7 & 0.7 & 0.4 & 29 & 21 & 32 \\
\hline Belgium & 0.4 & 0.3 & 0.3 & 15 & 23 & 26 \\
\hline France & 0.4 & 0.4 & 0.0 & 19 & 20 & 51 \\
\hline Germany & 0.5 & 0.7 & 0.5 & 29 & 30 & 29 \\
\hline Italy & 0.9 & 0.9 & 0.5 & 23 & 24 & 22 \\
\hline Netherlands & 0.3 & 0.8 & 0.7 & 25 & 25 & 31 \\
\hline Spain & 0.7 & 1.1 & 0.6 & 18 & 20 & 27 \\
\hline \multicolumn{7}{|l|}{ Memorandum: } \\
\hline United Kingdom & 1.1 & 1.0 & 0.8 & 29 & 37 & 43 \\
\hline United States & 1.0 & 0.7 & 1.7 & 24 & 30 & 35 \\
\hline Switzerland & 0.6 & 0.7 & 0.6 & 47 & 49 & 52 \\
\hline
\end{tabular}


Table 6

Bank share in financial intermediation in 1996

\begin{tabular}{|c|c|c|c|c|}
\hline \multirow[t]{3}{*}{ Countries } & \multicolumn{4}{|c|}{ Assets of banks as a percentage of assets of banks and non-bank financial institutions } \\
\hline & \multirow[t]{2}{*}{ Total } & \multicolumn{2}{|c|}{ of which } & \multirow{2}{*}{$\begin{array}{c}\text { Memo: } \\
\text { Share of state- } \\
\text { owned banks }\end{array}$} \\
\hline & & Savings banks & $\begin{array}{c}\text { Mutual and } \\
\text { cooperative banks }\end{array}$ & \\
\hline Austria & 85 & 26 & 21 & \\
\hline France & 70 & 8 & 15 & 11 \\
\hline Germany & 76 & 14 & 11 & 35 \\
\hline Italy & 77 & n.a. & 10 & 60 \\
\hline Netherlands & 57 & n.a. & n.a. & n.a. \\
\hline Spain & 75 & 26 & 3 & n.a. \\
\hline Memorandum: & & & & \\
\hline United Kingdom & $53^{2}$ & n.a. & n.a. & 0 \\
\hline United States & 26 & 4 & 1 & 0 \\
\hline Switzerland ${ }^{2}$ & 79 & 4 & 3 & $14^{3}$ \\
\hline
\end{tabular}

Table 7

Intrinsic strength and ordinary ratings of EU banks

\begin{tabular}{|c|c|c|c|c|}
\hline Countries & $\begin{array}{c}\text { Number of rated } \\
\text { banks }\end{array}$ & Range of BFSRs & Average BFSR & $\begin{array}{l}\text { Average long-term } \\
\text { deposit rating }\end{array}$ \\
\hline Austria & 7 & $\mathrm{C}+$ to $\mathrm{D}+$ & $\mathrm{C}+$ & $\mathrm{Aa} 3$ \\
\hline Belgium & 7 & $\mathrm{~B}+$ to $\mathrm{C}$ & $\mathrm{B}$ & $\mathrm{Aa} 3$ \\
\hline Denmark & 4 & $\mathrm{~B}$ to $\mathrm{C}$ & $\mathrm{C}+$ & A1 \\
\hline Finland & 4 & $\mathrm{D}+$ to $\mathrm{E}$ & $\mathrm{D}$ & $\mathrm{A} 2$ \\
\hline France & 22 & $\mathrm{~B}+$ to $\mathrm{E}+$ & $\mathrm{C}$ & A1 \\
\hline Germany & 21 & $\mathrm{~B}$ to $\mathrm{D}+$ & $\mathrm{C}+$ & Aa3 \\
\hline Ireland & 4 & $\mathrm{~B}$ to $\mathrm{C}$ & $\mathrm{C}+$ & A1/A2 \\
\hline Italy & 22 & $\mathrm{~B}$ to $\mathrm{E}$ & $\mathrm{C}$ & $\mathrm{A} 2$ \\
\hline Luxembourg & 3 & $\mathrm{~B}$ & B & $\mathrm{Aa} 2$ \\
\hline Netherlands & 7 & $\mathrm{~A}$ to $\mathrm{C}$ & $\mathrm{B}+$ & $\mathrm{Aa} 2$ \\
\hline Portugal & 3 & $\mathrm{C}$ to $\mathrm{D}+$ & $\mathrm{C}$ & A3 \\
\hline Spain & 11 & $\mathrm{~A}$ to $\mathrm{C}$ & B & $\mathrm{A} 1$ \\
\hline Sweden & 4 & $\mathrm{~B}$ to $\mathrm{C}$ & $\mathrm{C}+$ & A1 \\
\hline United Kingdom & 34 & $A$ to $D$ & $\mathrm{C}+$ & A1 \\
\hline
\end{tabular}


Table 8

Currency and home-country relationship in the choice of syndicated loan arranger, 1996

Percentage market share won by arrangers of indicated nationality

\begin{tabular}{|c|c|c|c|c|c|c|c|}
\hline \multicolumn{4}{|c|}{ German arranger banks } & \multicolumn{4}{|c|}{ French arranger banks } \\
\hline \multirow[t]{2}{*}{ Borrower } & \multicolumn{3}{|c|}{ Currency } & \multirow[t]{2}{*}{ Borrower } & \multicolumn{3}{|c|}{ Currency } \\
\hline & Mark & Other & All & & French franc & Other & All \\
\hline German & 82 & 71 & 80 & French & 46 & 10 & 39 \\
\hline Other & 46 & 3 & 4 & Other & 56 & 2 & 2 \\
\hline All & 62 & 3 & 4 & All & 47 & 2 & 3 \\
\hline \multirow{3}{*}{ Borrower } & \multicolumn{3}{|c|}{ UK arranger banks } & \multirow{2}{*}{\multicolumn{4}{|c|}{ US arranger banks }} \\
\hline & & Currenc & & & & & \\
\hline & Pound & Other & All & & Dollar & Other & All \\
\hline UK & 56 & 39 & 53 & US & 83 & 28 & 82 \\
\hline Other & 24 & 2 & 2 & Other & 27 & 13 & 20 \\
\hline All & 53 & 3 & 6 & All & 71 & 13 & 61 \\
\hline \multicolumn{8}{|c|}{$\begin{array}{l}\text { Note: Each entry shows the market share of German, French, UK or US banks as arrangers of loans for borrowers of the indicated } \\
\text { nationality in the indicated currency. For example, the } 82 \% \text { in the upper left-hand corner means that German banks arranged } 82 \% \text { of the } \\
\text { loans for German borrowers that were denominated in marks. Data include all loans in the Euromoney database that were signed and for } \\
\text { which amounts were given, and are therefore more inclusive than the usual data reported by the BIS, which exclude, inter alia, } \\
\text { refinancing. Total syndicated loan amounts by currency: Deutsche mark, } \$ 25 \text { billion; French franc, } \$ 31 \text { billion; pound, } \$ 102 \text { billion; } \\
\text { dollar, } \$ 1,254 \text { billion; grand total, } \$ 1,514 \text { billion. } \\
\text { Sources: Euromoney Bondware and BIS. }\end{array}$} \\
\hline
\end{tabular}


Table 9

Banks' restructuring: number of branches ${ }^{1}$

\begin{tabular}{|c|c|c|c|c|c|c|c|}
\hline \multirow[t]{2}{*}{ Countries } & $1980^{2}$ & 1990 & 1996 & \multicolumn{3}{|c|}{ Peak } & Bank \\
\hline & \multicolumn{4}{|c|}{ number (in thousands) } & year & $\%$ & density ${ }^{4}$ \\
\hline Austria & 3.3 & 4.5 & 4.7 & 4.7 & 1996 & - & 0.58 \\
\hline Belgium & 7.8 & 8.3 & 7.5 & 8.5 & 1989 & -11 & 0.74 \\
\hline France & 24.3 & 25.7 & 25.4 & 25.9 & 1987 & -2 & 0.44 \\
\hline Germany $^{5}$ & 39.3 & 39.8 & 38.2 & 40.0 & 1985 & -5 & 0.58 \\
\hline Italy & 12.2 & 17.7 & 24.9 & 24.9 & 1996 & - & 0.43 \\
\hline Netherlands & 6.6 & 8.0 & 6.8 & 8.5 & 1986 & -19 & 0.44 \\
\hline Spain & 25.8 & 35.2 & 37.1 & 37.1 & 1996 & - & 0.94 \\
\hline \multicolumn{8}{|l|}{ Memorandum: } \\
\hline United Kingdom & 20.4 & 19.0 & 15.3 & 21.2 & 1985 & -22 & 0.26 \\
\hline United States & 58.6 & 69.2 & 70.4 & 70.4 & 1996 & - & 0.27 \\
\hline Switzerland & 3.7 & 4.2 & 3.5 & 4.2 & 1990 & -15 & 0.50 \\
\hline
\end{tabular}

Table 10

Banks' restructuring: employment and staff costs

\begin{tabular}{|c|c|c|c|c|c|c|c|c|c|}
\hline \multirow[t]{3}{*}{ Countries } & \multicolumn{6}{|c|}{ Employment $^{1}$} & \multicolumn{3}{|c|}{ Staff costs ${ }^{2}$} \\
\hline & $1980^{3}$ & 1990 & $1996^{4}$ & \multicolumn{3}{|c|}{ Peak } & $\begin{array}{c}1980- \\
82^{5}\end{array}$ & $\begin{array}{c}1986- \\
88\end{array}$ & $\begin{array}{l}1992- \\
95\end{array}$ \\
\hline & \multicolumn{4}{|c|}{ number (in thousands) } & year & $\begin{array}{c}\% \\
\text { change }^{6}\end{array}$ & \multicolumn{3}{|c|}{$\begin{array}{l}\text { as a percentage of gross } \\
\text { income }\end{array}$} \\
\hline Belgium & 68 & 79 & 77 & 79 & 1990 & -3 & 42 & 33 & 40 \\
\hline France & 399 & 399 & 375 & 401 & 1988 & -7 & 50 & 46 & 43 \\
\hline Germany $^{7}$ & 533 & 696 & 750 & 758 & 1994 & -1 & 48 & 44 & 39 \\
\hline Italy & 277 & 324 & 332 & 333 & 1993 & -0.3 & 38 & 41 & 42 \\
\hline Netherlands & 113 & 117 & 112 & 118 & 1991 & -5 & 42 & 40 & 38 \\
\hline Spain & 252 & 252 & 242 & 256 & 1991 & -5 & 47 & 43 & 38 \\
\hline \multicolumn{10}{|l|}{ Memorandum: } \\
\hline United Kingdom & 324 & 425 & 373 & 430 & 1989 & -13 & 44 & 38 & 36 \\
\hline United States $^{8}$ & 1,900 & 1,979 & 1,893 & 2,136 & 1987 & -12 & 36 & 31 & 27 \\
\hline Switzerland & 84 & 120 & 104 & 120 & 1990 & -13 & 40 & 37 & 34 \\
\hline \multicolumn{10}{|c|}{$\begin{array}{l}{ }^{1} \text { In deposit-taking institutions. }{ }^{2} \text { For Austria, Belgium, Italy, the Netherlands and Switzerland, all banks; for other countries, } \\
\text { commercial banks (OECD definition). }{ }^{3} \text { For France, 1985; for the Netherlands, 1984; for Spain, } 1981 .{ }^{4} \text { For Italy, } 1995 .{ }^{5} \text { For } \\
\text { Austria, France, Italy and Belgium, 1981-82. }{ }^{6} \text { From peak to most recent observation where applicable. }{ }^{7} \text { For employment, western } \\
\text { Germany only in } 1980 .{ }^{8} \text { Employment data excluding credit unions: } 1996,1,722 \text {; percentage change, }-14 \% \text {. }\end{array}$} \\
\hline
\end{tabular}


Table 11

Merger and acquisition activity in banking 1

\begin{tabular}{|c|c|c|c|c|c|c|c|c|c|c|c|c|}
\hline \multirow[t]{3}{*}{ Countries } & \multirow{2}{*}{\multicolumn{4}{|c|}{ Number }} & \multicolumn{8}{|c|}{ Value } \\
\hline & & & & & \multicolumn{4}{|c|}{ in billions of US dollars } & \multicolumn{4}{|c|}{ as a percentage ${ }^{2}$} \\
\hline & $91-92$ & $93-94$ & $95-96$ & $97-98^{3}$ & $91-92$ & $93-94$ & $95-96$ & $97-98^{3}$ & $91-92$ & $93-94$ & $95-96$ & $97-98^{3}$ \\
\hline Austria & 35 & 19 & 21 & 7 & 1.7 & 0.4 & 1.4 & 2.8 & - & 16.8 & 65.3 & - \\
\hline Belgium & 22 & 18 & 12 & 7 & 1.0 & 0.6 & 0.4 & 5.1 & 14.1 & 7.0 & 4.4 & 71.3 \\
\hline France & 133 & 71 & 49 & 24 & 2.4 & 0.5 & 6.1 & 1.3 & 4.3 & 1.0 & 8.9 & 2.1 \\
\hline Germany & 71 & 83 & 36 & 25 & 3.5 & 1.9 & 1.0 & 19.3 & 6.5 & 7.6 & 4.0 & 54.6 \\
\hline Italy & 122 & 105 & 94 & 24 & 5.3 & 6.1 & 6.2 & 8.7 & 15.6 & 17.7 & 21.0 & 39.9 \\
\hline Netherlands & 20 & 13 & 8 & 8 & 0.1 & 0.1 & 2.2 & 0.4 & 0.2 & 0.5 & 13.7 & 1.2 \\
\hline Spain & 76 & 44 & 26 & 13 & 4.3 & 4.5 & 2.0 & 0.7 & 13.5 & 21.5 & 10.5 & 4 \\
\hline Total & 479 & 353 & 253 & 108 & 18.2 & 14.1 & 19.3 & 38.3 & 8.8 & 9.1 & 11.4 & 22.1 \\
\hline $\begin{array}{l}\text { Total non-bank } \\
\text { financial inst. }\end{array}$ & 827 & 687 & 709 & 273 & 18.2 & 22.8 & 32.7 & 44.2 & 8.8 & 14.7 & 9.2 & 25.6 \\
\hline Memorandum: ${ }^{4}$ & & & & & & & & & & & & \\
\hline \multirow{2}{*}{$\begin{array}{l}\text { United } \\
\text { Kingdom }\end{array}$} & 71 & 40 & 22 & 11 & 7.5 & 3.3 & 22.6 & 2.3 & 6.5 & 3.4 & 10.7 & 1.4 \\
\hline & 400 & 502 & 548 & 436 & 7.6 & 14.0 & 33.3 & 49.6 & 6.6 & 14.4 & 15.7 & 30.5 \\
\hline \multirow[t]{2}{*}{ United States } & 1,354 & 1,477 & 1,803 & 628 & 56.8 & 55.3 & 114.9 & 107.6 & 18.7 & 9.0 & 10.6 & 11.2 \\
\hline & 984 & 1,426 & 1,991 & 1,538 & 30.4 & 72.8 & 106.6 & 188.6 & 10.0 & 11.9 & 9.8 & 19.7 \\
\hline \multirow[t]{2}{*}{ Switzerland } & 47 & 59 & 27 & 17 & 0.4 & 3.9 & 0.5 & 23.0 & 9.5 & 43.4 & 1.2 & 90.1 \\
\hline & 30 & 30 & 54 & 21 & 0.4 & 2.0 & 1.9 & 10.4 & 9.7 & 21.9 & 4.6 & 40.7 \\
\hline
\end{tabular}


Table 12

Mergers and acquisitions

A subset of European bank M\&A activity in 1997-98

\begin{tabular}{|c|c|c|c|c|c|}
\hline Merging banks & Nationality & Sector & Expected date of merger & Objectives & $\begin{array}{l}\text { Relative size of } \\
\text { merging entities }\end{array}$ \\
\hline \multicolumn{6}{|l|}{ Austria } \\
\hline $\begin{array}{l}\text { First Austrian Savings Bank } \\
\text { GiroCredit }\end{array}$ & $\begin{array}{l}\text { AT } \\
\text { AT }\end{array}$ & $\begin{array}{l}\text { Bank } \\
\text { Bank }\end{array}$ & Completed September 1997. & $\begin{array}{ll} & \text { Rationalisation of costs. } \\
\text { - } & \text { Annual earnings growth of } 10 \% \text { predicted. Development of business in Eastern Europe via base } \\
\text { established by GiroCredit. } \\
\text { - Response to competitive threat posed by Bank Austria/Creditanstalt link-up. }\end{array}$ & Small/Big \\
\hline \begin{tabular}{|l} 
Bank Austria \\
Creditanstalt-Bankverein
\end{tabular} & $\begin{array}{l}\text { AT } \\
\text { AT }\end{array}$ & $\begin{array}{l}\text { Bank } \\
\text { Bank }\end{array}$ & $\begin{array}{l}\text { Purchased in } 1997 \text { but required to } \\
\text { remain separate legal entities } \\
\text { until } 2002 . \\
\end{array}$ & $\begin{array}{ll} & \text { Scope for cost savings, complementariness of domestic business. } \\
\text { Diversification outside domestic market via Creditanstalt's investment banking operations in } \\
\text { Central and Eastern Europe. }\end{array}$ & Equals \\
\hline \multicolumn{6}{|l|}{ Belgium } \\
\hline $\begin{array}{l}\text { Crédit Communal de Belgique } \\
\text { Crédit Local de France }\end{array}$ & $\begin{array}{l}\mathrm{BE} \\
\mathrm{FR} \\
\end{array}$ & $\begin{array}{l}\text { Bank } \\
\text { Bank } \\
\end{array}$ & $\begin{array}{c}\text { Completed end } 1996 . \\
\text { DEXIA holding company formed. }\end{array}$ & $\begin{array}{l}\text { - } \\
\text { - }\end{array}$ & Equals \\
\hline $\begin{array}{l}\text { ING } \\
\text { Banque Bruxelles Lambert }\end{array}$ & $\begin{array}{l}\mathrm{NL} \\
\mathrm{BE}\end{array}$ & $\begin{array}{c}\text { Bancassurance } \\
\text { Bank }\end{array}$ & $\begin{array}{c}\text { Completed Jan/Feb } 1998 . \\
\text { Purchase of } 95.57 \% \text { of shares. } \\
\text { Still separate legal entities. } \\
\end{array}$ & 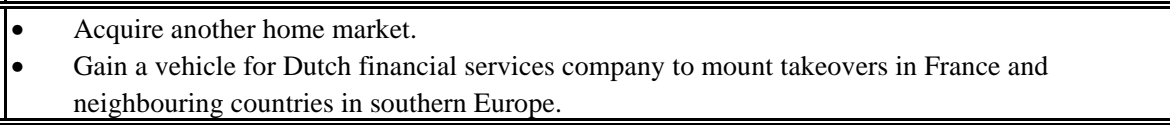 & Big/Small \\
\hline Fortis Group & BE/NL & Bancassurance & & - Widen range of financial products available to client base through diverse distribution network. & \\
\hline ASLK-CGER & $\mathrm{BE}$ & Bank & 1997 & $\begin{array}{l}\text { - } 74.9 \% \text { stake, under Fortis' ownership, ASLK-CGER, formerly state-owned, will better focus on } \\
\text { its core domestic retail banking. }\end{array}$ & Big/Small \\
\hline Mees Pierson & NE & Bank & 1997 & $\begin{array}{l}\text { - Integrated into Fortis Bank Nederland to create fourth-largest bank in the Netherlands. } \\
\text { - } \quad \text { MP's corporate strength complements Fortis Nederland's retail business. } \\
\text { - }\end{array}$ & Big/Small \\
\hline Générale de Banque & $\mathrm{BE}$ & Bank & $\begin{array}{l}\text { Directors of Générale agreed to } \\
\text { takeover by Fortis. Générale to be } \\
\text { parent of banking arm integrating } \\
\text { ASLK-CGER and Mees Pierson. } \\
\end{array}$ & $\begin{array}{l}\text { In line with Fortis strategy of providing a broad range of financial services to the retail market. } \\
\text { Cost savings of BF } 11 \text { bn estimated from rationalisation of operations and branch network. } \\
\text { Operational integration, due to start January 1999, will involve no compulsory redundancies; } \\
\text { savings are not promised in the first three years. }\end{array}$ & Big/Small \\
\hline \begin{tabular}{|l|} 
Kredietbank \\
Cera Bank \\
ABB Insurance
\end{tabular} & $\begin{array}{l}\mathrm{BE} \\
\mathrm{BE} \\
\mathrm{BE}\end{array}$ & $\begin{array}{c}\text { Bank } \\
\text { Bank } \\
\text { Insurance }\end{array}$ & 1st June 1998 & $\begin{array}{ll} & \text { KBC Holding to be formed under ownership of Almanij NV. } \\
\text { - } & \text { Goal: create bancassurance concern of competitive size. } \\
\text { - } & \text { Merger of three will create Belgium's largest bank with } 20 \% \text { share of deposits. } \\
\text { - } & \text { Econortunities for cross-selling insurance products. } \\
\end{array}$ & Big/Small \\
\hline
\end{tabular}


Table 12 (cont.)

\begin{tabular}{|c|c|c|c|c|c|}
\hline Merging banks & Nationality & Sector & Expected date of merger & Objectives & $\begin{array}{c}\text { Relative size of } \\
\text { merging entities }\end{array}$ \\
\hline \multicolumn{6}{|l|}{ France } \\
\hline $\begin{array}{l}\text { Caisse Centrale des Banques } \\
\text { Populaires } \\
\text { Natexis }\end{array}$ & $\begin{array}{l}\text { FR } \\
\text { FR }\end{array}$ & $\begin{array}{l}\text { Bank } \\
\text { Bank }\end{array}$ & $\begin{array}{l}\text { Purchased } 23.5 \% \text { stake in } \\
\text { Oct. } 1997 \text {, to be raised to } 67 \% \text {. }\end{array}$ & 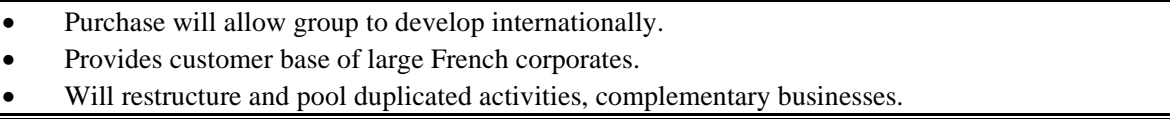 & Big/Small \\
\hline Société Générale & FR & Bank & & & \\
\hline (i) Hambros Bank & UK & Bank & Completed in March 1998. & - SoGe purchased Hambros / Hambros' bond business sold to Royal Bank of Canada. & Big/Small \\
\hline (ii) Cowen \& Co. & US & Bank & February 1998 & - $\quad$ Expansion into USD stock business. & Big/Small \\
\hline Crédit Agricole & $\overline{\mathrm{FR}}$ & Bank & & & \\
\hline Banque Indosuez & FR & Bank & 1996/97 & $\begin{array}{l}\text { - } \quad \text { Took majority stake in 1996, full control } 1997 . \\
\text { - }\end{array}$ & Big/Small \\
\hline Bankoa & ES & Bank & 1997 & - $\quad$ Building presence in Spain through Basque region. & Big/Small \\
\hline Banca Intesa & IT & Bank & 1997 & $\begin{array}{l}\text { - } \quad 30 \% \text { stake in Banca Intesa: Bank holding company of Banco Ambrosiano/Cariplo. } \\
\text { - Had 30\% stake in Ambrosiano since } 1995 .\end{array}$ & Big/Small \\
\hline $\begin{array}{l}\text { Crédit Mutuel } \\
\text { CIC }\end{array}$ & $\begin{array}{l}\text { FR } \\
\text { FR }\end{array}$ & $\begin{array}{l}\text { Bank } \\
\text { Bank }\end{array}$ & April 1998 & $\begin{array}{l}\text { - } \\
\text { - } \quad \text { CM will preserve jobs, use CIC for international expansion and continue cooperation with GAN. } \\
\text { - } \quad \text { Cost savings not primary consideration but should achieve economies of scale in certain areas. } \\
\quad \text { Produce country's third-largest retail bank with complimentary customer bases. }\end{array}$ & Equals \\
\hline
\end{tabular}

\section{Germany}

\begin{tabular}{|c|c|c|c|c|c|}
\hline Bankgesellschaft Berlin (BGB) & $\mathrm{DE}$ & Bank & & - $\quad$ Group exists since merger of Berliner Bank, Berliner Hyp. and Landesbank Berlin in 1994. & \\
\hline Norddeutsche Landesbank & $\mathrm{DE}$ & Bank & To be finalised end-May 1998. & Norddeutsche Landesbank to become part of BGB holding but will retain its public guarantees. & Equals \\
\hline Bayerische Vereinsbank & $\overline{\mathrm{DE}}$ & Bank & & & \\
\hline Hypo-Bank & $\mathrm{DE}$ & Bank & 1st September 1998 & $\begin{array}{l}\text { - } \quad \text { Cost savings of } 13 \% \text { expected. } \\
\text { - } \quad \text { Creation of country's second-largest bank and solidify strong regional presence. } \\
\text { New entity will assume the debt of Hypo-Bank. }\end{array}$ & Equals \\
\hline Noris Verbaucher Bank & $\mathrm{DE}$ & Bank & June 1997 & - $\quad$ Purchase of consumer finance specialist to expand on existing domestic operations. & Big/Smal \\
\hline Dresdner Bank & $\mathrm{DE}$ & Bank & & & \\
\hline (i) Advance Bank & $\mathrm{DE}$ & Bank & December 1997 & - $\quad$ Addition of direct banking unit to domestic operations. & Big/Small \\
\hline (ii) Kleinwort Benson Iberfomento & ES & Bank & February 1998 & $\begin{array}{l}\text { To capture growing slice of Spanish corporate acquisitions market in Latin America } \\
\text { - } \quad \text { Part of wider global ambitions. }\end{array}$ & Big/Small \\
\hline (iii) Allianz & $\mathrm{DE}$ & Insurance & 1998 & - Talks about increased cooperation in asset management. & $\mathrm{Big} / \mathrm{Big}$ \\
\hline $\begin{array}{l}\text { Deutsche Girozentrale } \\
\text { Deka Bank }\end{array}$ & $\begin{array}{l}\mathrm{DE} \\
\mathrm{DE}\end{array}$ & $\begin{array}{l}\text { Bank } \\
\text { Bank } \\
\end{array}$ & 1997 & - Expansion of fund management activities. & Big/Small \\
\hline \begin{tabular}{|l|l} 
Deutsche Bank \\
Bankhaus Grunelius
\end{tabular} & $\begin{array}{ll}\mathrm{DE} \\
\mathrm{DE}\end{array}$ & $\begin{array}{l}\text { Bank } \\
\text { Bank } \\
\end{array}$ & 1997 & Bought a $16 \%$ stake as nucleus for private banking activity. & Big/Small \\
\hline $\begin{array}{l}\text { Landeskreditbank BW } \\
\text { Südwestdeutsche Landesbank } \\
\text { Landesgirokasse }\end{array}$ & $\begin{array}{l}\mathrm{DE} \\
\mathrm{DE} \\
\mathrm{DE}\end{array}$ & $\begin{array}{l}\text { Bank } \\
\text { Bank } \\
\text { Bank }\end{array}$ & December 1998 & $\begin{array}{l}\text { Form Germany's second-largest public sector bank. } \\
\text { - } \\
\text { Provide major competitive threat in local retail market and put pressure on local savings banks. } \\
\text { Create viable regional banking concern in the state of Baden-Württemberg. }\end{array}$ & Equals \\
\hline
\end{tabular}


Table 12 (cont.)

\begin{tabular}{|c|c|c|c|c|c|}
\hline Merging banks & Nationality & Sector & Expected date of merger & Objectives & $\begin{array}{l}\text { Relative size of } \\
\text { merging entities }\end{array}$ \\
\hline \multicolumn{6}{|l|}{ Italy } \\
\hline $\begin{array}{l}\text { BCI } \\
\text { Banca di Roma }\end{array}$ & $\begin{array}{l}\text { IT } \\
\text { IT } \\
\text { IT }\end{array}$ & $\begin{array}{l}\text { Bank } \\
\text { Bank } \\
\text { Bank }\end{array}$ & Proposed merger. & $\begin{array}{l}\text { - } \\
\text { - } \quad \text { No talks yet. } \\
\text { - } \\
\text { Response to heightened competition through EMU. }\end{array}$ & Equals \\
\hline $\begin{array}{l}\text { Banca Nazionale del Lavoro } \\
\text { Banco di Napoli } \\
\text { INA }\end{array}$ & $\begin{array}{l}\text { IT } \\
\text { IT } \\
\text { IT }\end{array}$ & $\begin{array}{l}\text { Bank } \\
\text { Bank } \\
\text { Insurance }\end{array}$ & October 1998 & $\begin{array}{l}\text { - } \\
\text { BNL \& INA established joint venture to purchase stake in Banco di Napoli. } \\
\text { BNL and Banco di Napoli to be integrated gradually with a view to full merger. } \\
\text { Focus on retail banking. }\end{array}$ & Equals \\
\hline $\begin{array}{l}\text { Cariplo } \\
\text { Ambroveneto }\end{array}$ & $\begin{array}{l}\text { IT } \\
\text { IT }\end{array}$ & $\begin{array}{l}\text { Bank } \\
\text { Bank }\end{array}$ & June 1998 & $\begin{array}{l}\text { - Separate branch networks to be maintained under holding company structure (Banca Intesa), } \\
\text { so not cost-driven: strategic alliance. }\end{array}$ & Equals \\
\hline $\begin{array}{l}\text { Credito Italiano } \\
\text { Unicredito }\end{array}$ & $\begin{array}{l}\text { IT } \\
\text { IT }\end{array}$ & $\begin{array}{l}\text { Bank } \\
\text { Bank }\end{array}$ & Uncertain. & $\begin{array}{l}\text { - } \\
\text { - } \\
\text { - }\end{array}$ & Equals \\
\hline $\begin{array}{l}\text { Istituto Bancario San Paolo di T. } \\
\text { Istituto Mobiliare Italiano (IMI) }\end{array}$ & $\begin{array}{l}\text { IT } \\
\text { IT }\end{array}$ & $\begin{array}{l}\text { Bank } \\
\text { Bank }\end{array}$ & $\begin{array}{l}\text { Shareholder meeting July } 1998 . \\
\text { San Paolo will hold } 55.3 \% \text { of the } \\
\text { new company and IMI } 44.7 \% \text {. }\end{array}$ & $\begin{array}{l}\text { - } \\
\text { - } \quad \text { Strengthen domestic position. } \\
\text { - } \quad \text { Expoct to be able to cut costs by ITL } 350 \text { bn per year starting in } 2000 \text {. }\end{array}$ & Equals \\
\hline
\end{tabular}

\section{Netherlands}

\begin{tabular}{|c|c|c|c|c|c|}
\hline ING & NL & Bancassurance & & & \\
\hline $\begin{array}{l}\text { Banque Bruxelles Lambert } \\
\text { (see above: Belgium) }\end{array}$ & $\mathrm{BE}$ & Bank & $\begin{array}{l}\text { Completed January/February } 1998 . \\
\text { Purchase of } 95.57 \% \text { of shares. } \\
\text { Still separate legal entities. } \\
\end{array}$ & $\begin{array}{l}\text { Acquire another home market. } \\
\text { Gain a vehicle for Dutch financial services company to mount takeovers in France and } \\
\text { neighbouring countries in southern Europe. }\end{array}$ & Big/Small \\
\hline Allgemeine Deutsche Direktbank & $\mathrm{DE}$ & Bank & March 1998 & - $\quad 49 \%$ stake. Expand telephone-banking business into Germany ahead of EMU. & Big/Small \\
\hline
\end{tabular}




\section{Graphs}

Graph 1

Long-term credit rating of major banks *
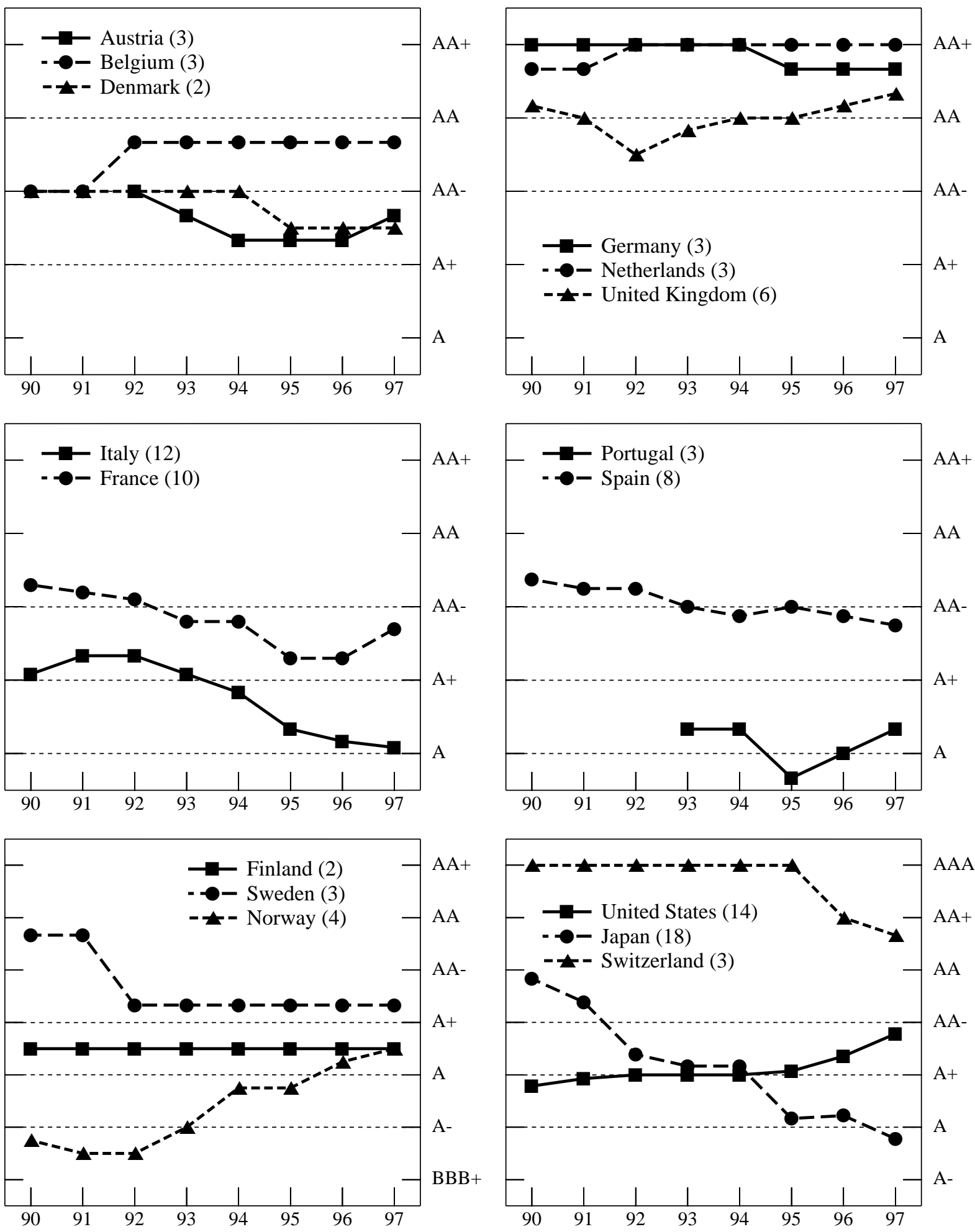

* Average of banks' rating at the end of the year. Data in brackets indicate the number of banks included. Source: IBCA. 


\section{References}

Bank for International Settlements (1998): International banking and financial market developments, February.

Bank for International Settlements (1996): 66th Annual Report, June.

Barth, James R., Daniel E. Nolle and Tara N. Rice (1996): "Commercial banking structure, regulation, and performance: an international comparison". Working Paper (draft), Office of the Comptroller of the Currency.

Basle Committee on Banking Supervision (1995): An internal model-based approach to market risk capital requirements. Bank for International Settlements, April.

Berlin, Mitchell and Loretta J. Mester (1996): "Why is the banking sector shrinking?" Working Paper No. 96-18, Federal Reserve Bank of Philadelphia.

Borio, Claudio and Costas Tsatsaronis (1996): "Restructuring in banking: the role of mergers and acquisitions". Paper presented at the conference Toward a common European banking market: national strategies and policy issues, Paolo Baffi Centre for Financial and Monetary Economics, Bocconi University, Milan, 10th May.

Chernow (1997): The death of the banker. New York: Vintage.

Chrystal, Alec K. and Cletus C. Coughlin (1992): "How the 1992 legislation will affect European financial services". Review, The Federal Reserve Bank of St. Louis, March/April.

Claessens, Stijn, Asli Demirgüc-Kunt and Harry Huizinga (1998): "How does foreign entry affect the domestic banking market?" Working Paper, World Bank (forthcoming).

Craig, Ben (1997): “The long-run demand for labour in the banking industry". Quarterly Economic Review, The Federal Reserve Bank of Cleveland, 4th quarter, pp. 23-33.

Crockett, Andrew (1998): "A broad view: evolution of the banking industry and the regulatory response". Emerald City Bank... banking in 2010. Centre for the Study of Financial Innovation, March, pp. 7-10.

Davis, Philip E. (1996): "The role of institutional investors in the evolution of financial structure and behaviour". Reserve Bank of Australia, The future of the financial system (proceedings of a conference), Kirribilli, 8th-9th July, pp. 49-99.

Dermine, Jean (1997): European capital markets with a single currency: an overview. Paper presented at INSEAD, Fontainebleau, September.

Dickson, Martin (1998): “Turmoil clips Asia's wings”. The Financial Times, FT 500, 22nd January, p. 8.

Economic Research Europe Ltd. (1996): A study of the effectiveness and impact of internal market integration on the banking and credit sector, September.

Freedman, Charles and Clyde Goodlet (1998): "The financial services sector: past changes and future prospects". Technical Report No. 82, Bank of Canada.

Gros, Daniel and Karel Lannoo (1996): "The passage to the euro". Working Party Report No. 16, Centre for European Policy Studies, December. 
Gual, Jordi and Damien Neven (1993): "Deregulation of the European banking industry". European Economy/Social Europe, No. 3, pp. 151-83.

House, Richard (1998): “Europe's year of the deal”. Institutional Investor, January, pp. 51-5.

Jack, Andrew (1997): "French regulator may punish banks that undercut rivals". The Financial Times, 1st July, p. 16.

Jeanneau, Serge (1996): “The market for international asset-backed securities". International banking and financial market developments, Bank for International Settlements, November, pp. 36-46.

Llewellyn, David T. (1996): "Banking in the 21st century: the transformation of an industry". Reserve Bank of Australia, The future of the financial system (proceedings of a conference), Kirribilli, 8th-9th July, pp. 141-79.

Martin, Peter (1998): “What's in a name?” The Financial Times, 26th February, p. 12.

McCauley, Robert N. and William R. White (1997): "The euro and European financial markets". Working Papers No. 41, Bank for International Settlements, May.

McGrath, John (1997): "Bank reform goes only skin deep". Euromoney, September, pp. 401-2.

Moody's (1998): “European banks: towards EMU and beyond”. Moody's Outlook, January.

Moody's Investors Service (1997): “An outlook for the support mechanisms of German public-sector banks". Report No. 25816, August.

Morgan Stanley Dean Witter (1998): The competitive edge. 14th January.

Organisation for Economic Co-operation and Development (1996): "Public policy and financial market access in the global economy". DAFFE/CMF(96)19/REV1.

Owen, Jo (1997): “A fear in the future”. The Banker, May, pp. 28-9.

Price Waterhouse (1988): “The economics of 1992”. European Economy, Brussels, No. 35, March.

Resti, Andrea (1996): "Fallen angels or money-pumps? Trying to draw a map of the main European banks". Research Papers in Banking and Finance, RP 96/17, Institute of European Finance.

Rhoads, Christopher and Silivia Ascarelli (1998): "Branching out". Wall Street Journal, 8th January, pp. 1,7 .

Stewart, Alan (1997): "Retail revolution ahead". The Financial Times Review, 2nd July, pp. 6-7.

Tucker, Emma (1997): “Lift for cross-border banking”. The Financial Times, 1st July, p. 2.

Vander Vennet, Rudi (1997): "Determinants of EU bank takeovers: a logit analysis". Working Paper No. 97/29, University of Ghent, April.

Vander Vennet, Rudi (1995): "The effect of mergers and acquisitions on the efficiency and profitability of EC credit institutions”. Working Paper No. 95/07, University of Ghent, April.

Zimmerman (1995): "Implementing the single banking market in Europe". Economic Review No. 3, Federal Reserve Bank of San Francisco, pp. 35-51. 



\section{Recent BIS Working Papers}

No.

38

October 1996

39

January 1997

40

March 1997

41

May 1997

42

June 1997

43

July 1997

44

July 1997

45

August 1997

46

September 1997

47

September 1997

48

September 1997

49

September 1997

50

November 1997

51

November 1997

52

January 1998

53

March 1998
Title

International agreements in the area of banking and

finance: accomplishments and outstanding issues

Banking system failures in developing and transition

countries: diagnosis and prediction

Monetary policy operating procedures in industrial

countries

The euro and European financial markets

Measuring monetary policy shocks in France, Germany and Italy: the role of the exchange rate

Exchange rate regimes and the expectations hypothesis of the term structure

Is there excess comovement of bond yields between countries?

A multi-country comparison of the linkages between inflation and exchange rate competitiveness

Global asset allocation in fixed income markets

Financial asset prices and monetary policy: theory and evidence

Some multi-country evidence on the effects of real exchange rates on output

Why does the yield curve predict economic activity? Dissecting the evidence for Germany and the United States

The euro and the dollar

Forecast errors and financial developments

Inflation and disinflation in Iceland

Exchange rate regimes and inflation and output in SubSaharan countries
Palle S. Andersen and Már Guðmundsson

Author

William R. White

Patrick Honohan

Claudio E. V. Borio

Robert N. McCauley and William R. White

Frank Smets

Stefan Gerlach and Frank Smets

Gregory D. Sutton

Steven B. Kamin

Srichander

Ramaswamy

Frank Smets

Steven B. Kamin

Frank Smets and Kostas Tsatsaronis

Robert N. McCauley

Palle S. Andersen

Marc Klau and Marc Klau 